\title{
Transcatheter aortic valve replacement with Lotus and Sapien 3 prosthetic valves: a systematic review and meta-analysis
}

\author{
Mirosław Gozdek ${ }^{1}$, Jakub Ratajczak ${ }^{1}$, Adam Arndt ${ }^{2}$, Kamil Zieliński ${ }^{3}$, Michał Pasierski ${ }^{4}$, \\ Matteo Matteucci ${ }^{5,6}$, Dario Fina ${ }^{5,7}$, Federica Jiritano, ${ }^{5,8}$, Paolo Meani ${ }^{5,9}$, Giuseppe Maria Raffa ${ }^{10}$, \\ Pietro Giorgio Malvindi ${ }^{11}$, Michele Pilato ${ }^{10}$, Domenico Paparella ${ }^{11,12}$, Artur Słomka ${ }^{13}$, Uri Landes ${ }^{14}$, \\ Ran Kornowski ${ }^{14}$, Jacek Kubica ${ }^{1}$, Roberto Lorusso ${ }^{5}$, Piotr Suwalski ${ }^{4}$, Mariusz Kowalewski ${ }^{4,5,15}$; on behalf \\ of Thoracic Research Centre
}

\begin{abstract}
${ }^{1}$ Department of Cardiology and Internal Medicine, ${ }^{2}$ Department of Anesthesiology and Intensive Therapy, Collegium Medicum, Nicolaus Copernicus University, Bydgoszcz, Poland; ${ }^{3}$ Warsaw Medical University, Warsaw, Poland; ${ }^{4}$ Clinical Department of Cardiac Surgery, Central Clinical Hospital of the Ministry of Interior and Administration, Centre of Postgraduate Medical Education, Warsaw, Poland; ${ }^{5}$ Department of Cardio-Thoracic Surgery, Heart and Vascular Centre, Maastricht University Medical Centre, Cardiovascular Research Institute Maastricht (CARIM), Maastricht, The Netherlands; ${ }^{6}$ Department of Cardiac Surgery, Circolo Hospital, University of Insubria, Varese, Italy; ${ }^{7}$ Cardiovascular Intensive Care, IRCCS Policlinico San Donato, Milan, Italy; ${ }^{8}$ Cardiac Surgery Unit, Department of Experimental and Clinical Medicine, Magna Graecia University, Catanzaro, Italy; ${ }^{9}$ Department of Intensive Care Unit, Maastricht University Medical Centre (MUMC+), Maastricht, The Netherlands; ${ }^{10}$ Department for the Treatment and Study of Cardiothoracic Diseases and Cardiothoracic Transplantation, IRCCS-ISMETT (Instituto Mediterraneo per i Trapianti e Terapie ad alta specializzazione), Palermo, Italy; ${ }^{11}$ Wessex Cardiothoracic Centre, University Hospital Southampton, Southampton, UK; ${ }^{12}$ Department of Emergency and Organ Transplant, University of Bari Aldo Moro, Bari, Italy; ${ }^{13}$ Department of Pathophysiology, Collegium Medicum, Nicolaus Copernicus University, Bydgoszcz, Poland; ${ }^{14}$ Department of Cardiology, Institute of Interventional Cardiology, Rabin Medical Center, Petach Tikva and Tel Aviv University, Tel Aviv, Israel; ${ }^{15}$ Thoracic Research Centre, Collegium Medicum, Nicolaus Copernicus University, Innovative Medical Forum, Bydgoszcz, Poland

Contributions: (I) Conception and design: M Gozdek, M Matteucci, D Fina, F Jiritano, P Meani, GM Raffa, PG Malvindi, A Słomka, M Kowalewski; (II) Administrative support: M Pilato, D Paparella, U Landes, R Kornowski, J Kubica, R Lorusso, P Suwalski, M Kowalewski; (III) Provision of study materials or patients: M Gozdek, J Ratajczak, A Arndt, K Zieliński, M Pilato, M Kowalewski; (IV) Collection and assembly of data: M Gozdek, J Ratajczak, A Arndt, K Zieliński, M Pasierski, M Matteucci, D Fina, F Jiritano, P Meani; (V) Data analysis and interpretation: M Gozdek, GM Raffa, PG Malvindi, M Kowalewski; (VI) Manuscript writing: All authors; (VII) Final approval of manuscript: All authors.

Correspondence to: Mariusz Kowalewski, MD. Clinical Department of Cardiac Surgery, Central Clinical Hospital of the Ministry of Interior and Administration, Centre of Postgraduate Medical Education, Wołoska Str. 137, 02-507 Warsaw, Poland. Email: kowalewskimariusz@gazeta.pl.
\end{abstract}

Background: Frequent occurrence of paravalvular leak (PVL) after transcatheter aortic valve replacement (TAVR) was the main concern with early-generation devices and focused technological improvements. Current systematic review and meta-analysis sought to compare outcomes of TAVR for severe native valve stenosis with next-generation devices: Lotus and Sapien 3.

Methods: Electronic databases were screened for studies comparing outcomes of TAVR with Lotus and Sapien 3. In a random-effects meta-analysis, the pooled incidence rates of procedural, clinical and functional outcomes according to VARC-2 definitions were assessed.

Results: Eleven observational studies including 2,836 patients (Lotus N=862 vs. Sapien 3 N=1,974) met inclusion criteria. No differences were observed regarding composite endpoints-device success and early safety. Similarly, 30-day mortality, major vascular complications, acute kidney injury and serious bleeding events were similar with both devices. Lotus valve demonstrated $35 \%$ reduction of the risk for mild PVL: risk ratio (RR) $0.65,95 \%$ confidence interval (CI): $0.49-0.85, \mathrm{P}=0.002$; but there were no statistical differences with regard to moderate/severe PVL (RR 0.56, 95\% CI: 0.18-1.77, P=0.320). Lotus valves produced significantly higher mean transaortic gradients: mean difference (MD) $0.88 \mathrm{mmHg}, 95 \% \mathrm{CI}$, 0.24-1.53 mmHg, $\mathrm{P}=0.007$; however, without translation into higher rate of prosthesis-patient mismatch (RR 1.10, 95\% CI: 0.82-1.47, P=0.540). As compared to Sapien 3, Lotus device placement was associated with significantly higher rate of permanent pacemaker implantation (RR 2.30, 95\% CI: 1.95-2.71, $\mathrm{P}<0.00001$ )

(C) Journal of Thoracic Disease. All rights reserved. 
and cerebrovascular events (RR 1.76, 95\% CI: 1.03-2.99, P=0.040).

Conclusions: Lotus valve, as compared with Sapien 3, was associated with lower risk for PVL but higher risk for permanent pacemaker implantation and cerebrovascular events.

Keywords: Meta-analysis; Lotus; Sapien 3; transcatheter aortic valve replacement (TAVR)

Submitted Jun 25, 2019. Accepted for publication Nov 19, 2019.

doi: $10.21037 /$ jtd.2019.12.107

View this article at: http://dx.doi.org/10.21037/jtd.2019.12.107

\section{Introduction}

Since introduction by Cribier in 2002 (1), transcatheter aortic valve replacement (TAVR) has been complementary method to surgical aortic valve replacement (SAVR) in inoperable or high-risk patients with severe symptomatic aortic stenosis. Similar (2) or even lower (3) 1-year mortality rate of TAVR, as compared to SAVR was shown in selected groups of patients. Hence, TAVR is now considered as an alternative treatment option and is recommended not only in inoperable, high or increased risk surgical patients (2-5) but also in intermediate risk individuals (6-9).

Commercially available within initial few years after the first procedure early generation transcatheter valves, despite providing good clinical outcomes, were not free from drawbacks like high rate of conduction abnormalities, vascular complications or more importantly higher incidence of paravalvular leak (PVL), which in turn was associated with increased late mortality and higher rate of adverse clinical incidents as compared to SAVR (10-13).

To minimize these shortcomings technological innovations were developed in next-generations valves, which included among others: balloon-expandable Sapien 3 (Edwards Lifesciences, Irvine, California, USA) and mechanically-expanded, repositionable and retrievable Lotus Valve System (Boston Scientific Corporation, Marlborough, Massachusetts, USA).

The objective of the present investigation was to evaluate and compare short-term results of transcatheter aortic valve implantation with Lotus and Sapien 3 in patients presenting with symptomatic severe native aortic valve stenosis.

\section{Methods}

\section{Data sources and search strategy}

The systematic review and meta-analysis was performed in accordance to the MOOSE statement $(14,15)$. The MOOSE checklist is available as Table S1. We searched
PubMed, ClinicalKey, the Web of Science and Google Scholar as well as congress proceedings from major cardiothoracic and cardiology societies meetings, all until December 2018. Search terms were: "Lotus- or Sapien 3- or Lotus versus Sapien 3-, transcatheter valve". The literature was limited to articles published in English. References of original articles were reviewed manually and cross-checked. Abstracts were eligible for detailed assessment when were available online and reported outcomes of interest.

\section{Selection criteria and quality assessment}

Studies were included if having met all of the following criteria: (I) human study; (II) study or study arms comparing directly or indirectly strategy of TAVR with Lotus and Sapien 3. Studies were excluded if: (I) in-vitro study; (II) not reporting outcomes of interest. No restrictions regarding type of the study, number of patients included or characteristic of the population were imposed.

Two reviewers (M Gozdek and J Ratajczak) selected the studies for the inclusion, extracted studies and patients' characteristics of interest and relevant outcomes. Two authors (M Gozdek and J Ratajczak) independently assessed the trials' eligibility and risk of bias. Any divergences were resolved by consensus.

Quality of observational studies was appraised with ROBINS-I (Risk of Bias in Nonrandomised Studiesof Interventions), a tool used for assessment of the bias (the selection of the study groups; the comparability of the groups; and the ascertainment of either the exposure or outcome of interest) in cohort studies included in a systematic review and/or meta-analysis (16).

\section{Endpoints selection}

Endpoints were established according to the Valve Academic Research Consortium-2 (VARC-2) definitions (17). Procedural outcomes of interest were: use of more than 1 
prosthesis during initial implantation and repeat procedure for valve-related dysfunction in 30 days. Clinical endpoints assessed included: permanent pacemaker implantation (PPI), major vascular complications (MVC), serious bleeding (life-threatening and/or major), acute kidney injury (AKI), cerebrovascular events (CVE) and 30-day mortality. Functional outcomes were: mean transprosthetic gradient, prosthesis-patient mismatch (PPM), mild and moderate to severe PVL. Composite endpoints were: device success and early safety. Additionally, procedure duration, rates of predilatation and postdilatation as well as contrast volume and other non-VARC-2 endpoints, were also considered. To assess PPM incidence, we pooled data expressed by authors as indexed effective orifice area (iEOA) $<0.85 \mathrm{~cm}^{2} / \mathrm{m}^{2}$ and as a mean transaortic gradient $>20 \mathrm{mmHg}$. We also included data for analysis in cases where the authors only pointed out PPM without specifying values and units.

\section{Statistical analysis}

Data were analysed according to intention-to-treat principle wherever applicable. Risk ratios (RRs) and 95\% confidence intervals (95\% CIs) served as primary index statistics for dichotomous outcomes. For continuous outcomes, mean difference (MD) and corresponding 95\% CI were calculated using random effects model. To overcome the low statistical power of Cochran $\mathrm{Q}$ test, the statistical inconsistency test $\mathrm{I}^{2}=\left[\left(\mathrm{Q} \_\mathrm{df}\right) / \mathrm{Q}\right] \times 100 \%$, where $\mathrm{Q}$ is the chi-square statistic and $\mathrm{df}$ is degrees of freedom, was used to assess heterogeneity (18). It examines the percentage of interstudy variation, with values ranging from $0 \%$ to $100 \%$. An $\mathrm{I}^{2}$ value of less than $40 \%$ indicates no obvious heterogeneity, values between $40-70 \%$ are suggestive of moderate heterogeneity and $\mathrm{I}^{2}$ more than $70 \%$ is considered as high heterogeneity.

Because of high degree of heterogeneity anticipated among the present only nonrandomized trials, an inverse variance (DerSimonian-Laird) random-effects model was applied as a more conservative approach for observational data accounting for between- and within-study variability. Whenever a single study reported median values and interquartile ranges instead of mean and standard deviation (SD), the latter were approximated as described by Wan and colleagues (19). In case there were " 0 events" reported in both arms, calculations were repeated, as a sensitivity analysis, using risk difference (RD) and respective 95\% CI. Review Manager 5.3 (The Nordic Cochrane Centre, Copenhagen, Denmark) was used for statistical computations. $\mathrm{P}$ values $\leq 0.05$ were considered statistically significant and reported as two-sided, without adjustment for multiple comparisons.

\section{Results}

\section{Study selection}

Study selection process and reasons for exclusion of some studies are described in Figure 1. Systematic search of the online databases allowed collection of 255 potentially eligible records that were retrieved for scrutiny. Of those, 244 were further excluded because they were not pertinent to the design of the meta-analysis or did not meet the explicit inclusion criteria. Eleven observational studies (20-30) [among them two multicentre registries $(22,25)$ ] enrolling 2,836 patients were eventually included in the analysis. Potential sources of the studies' bias were analyzed with the use of components recommended by the ROBINS-I tool and the results are enclosed as Table $S 2$. Overall, the studies reported either moderate or serious risk of bias. Most commonly biases arose from participants selection for the study by designated heart teams and subjective distribution of the participants within the study arms by designated operators. Patients were divided into two groups: those treated with Lotus transcatheter valve $(\mathrm{N}=862)$ and Sapien 3 transcatheter valve $(\mathrm{N}=1,974)$.

Summary of the valve characteristics is available as Figure 2. Studies' characteristics as well as definitions or diagnostic criteria for assessed clinical endpoints are reported in Table 1. Table $S 3$ lists selection criteria for the procedure and valve as well as inclusion and exclusion criteria within particular studies. Patients' baseline characteristics and detailed procedural characteristics are available as Tables $S 4, S 5$. All studies reported data on 30-day clinical outcomes and 5 reported data of longer-term follow-up.

\section{Patients characteristic}

Groups treated with Lotus and Sapien 3 did not differ regarding patients' age $(\mathrm{P}=0.886)$ and NYHA III/IV status $(\mathrm{P}=0.300)$. Lotus group included significantly more female individuals, $50.8 \%$ vs. $45.3 \%$, respectively $(\mathrm{P}=0.010)$ and significantly more often suffered from chronic kidney disease $(24.7 \%$ vs. $17.1 \%, \mathrm{P}=0.005)$. There was a statistically significant difference in Logistic EuroSCORE (17.4 \pm 13.3 vs. $14.5 \pm 10.2 ; \mathrm{P}<0.0001)$ and STS risk profile $(5.6 \pm 4.5$ vs. 


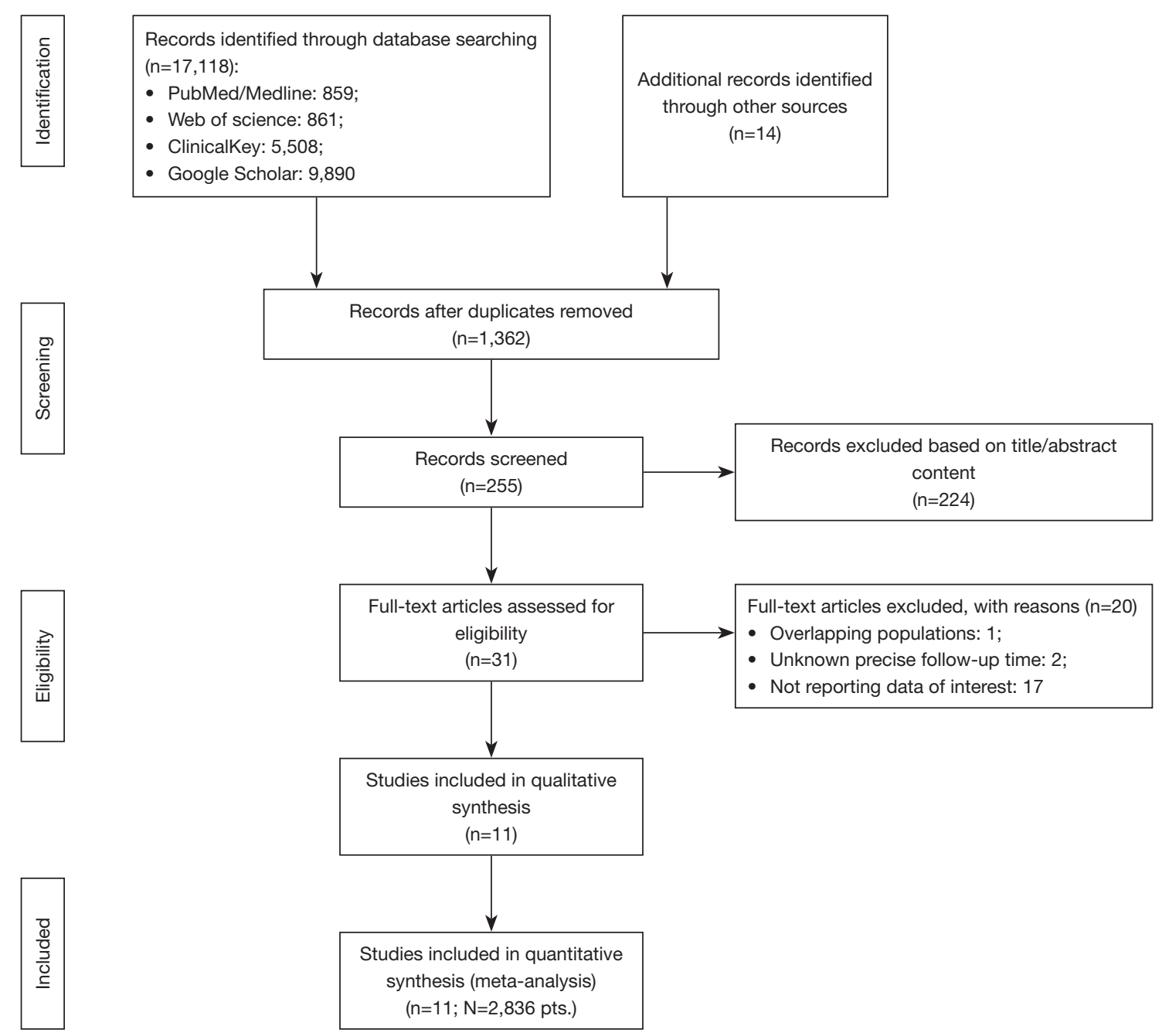

Figure 1 Study selection and inclusion process.

6.1 $\pm 4.0 ; \mathrm{P}=0.017$ ) for Sapien 3 and Lotus, respectively. Aortic valve baseline echo-parameters, i.e., mean trans-aortic gradient and effective orifice area were comparable $(\mathrm{P}=0.670$ and $\mathrm{P}=0.791$ respectively). Despite comparable native annulus diameter $(24.36 \pm 6.24$ vs. $24.78 \pm 2.31$ for Lotus and Sapien 3 respectively, $\mathrm{P}=0.087$ ) patients in Lotus group received smaller prostheses; mean size of implanted valve was $25.10 \mathrm{~mm}$ in Lotus and $25.99 \mathrm{~mm}$ in Sapien 3 patients $(\mathrm{P}<0.001)$.

Transfemoral access was mostly employed during TAVR procedure (99\% Sapien 3 and 100\% Lotus) followed by transapical $(0.94 \%)$ and transsubclavian $(0.06 \%)$ in Sapien 3 recipients.

\section{Procedural outcomes}

There were no marked differences in rates of predilatation (RR $0.77,95 \%$ CI: $0.56-1.07, \mathrm{P}=0.120 ; \mathrm{I}^{2}=94 \%$ ) while postdilatation was performed less frequently in Lotus recipients (RR 0.10, 95\% CI: $0.03-0.31, \mathrm{P}=0.0001 ; \mathrm{I}^{2}=0 \%$ ) (Figure $S 1 A, B)$. At least one recapture manoeuvre to optimize valve deployment was performed in $37.53 \%$ of the Lotus recipients (167 of 445).

The procedures performed with Lotus required significantly greater amount of contrast: $166.3 \pm 69.7 \mathrm{vs}$. $130.4 \pm 57.7 \mathrm{~mL}$ (MD 32.85, 95\% CI: 10.64-55.07, P=0.004) (Figure $51 C$ ). 


\begin{tabular}{|c|c|}
\hline Lotus (Boston Scientific Corporation) & Sapien 3 (Edwards Lifesciences) \\
\hline 35 & $=\cos ^{2}=0$ \\
\hline Bovine pericardial leaflet tissue & Bovine pericardial leaflet tissue \\
\hline Mechanically expandable braided nitinol frame & Balloon-expandable cobalt-chromium frame \\
\hline \multicolumn{2}{|l|}{ Transfemoral sheath size (valve size) } \\
\hline $18 \mathrm{~F}(23 \mathrm{~mm}), 20 \mathrm{~F}(25,27 \mathrm{~mm})$ & $\begin{array}{l}\text { Ready for ultra-low profile: } 14 \mathrm{~F}(20,23,26 \mathrm{~mm}) ; 16 \mathrm{~F}(29 \mathrm{~mm}) \text {, } \\
18 \mathrm{~F}(20,23,26 \mathrm{~mm}), 21 \mathrm{~F}(29 \mathrm{~mm})\end{array}$ \\
\hline \multicolumn{2}{|l|}{ Special features } \\
\hline $\begin{array}{l}\text { - Adaptive seal at the inflow } \\
\text { - Fully retrievable and repositionable } \\
\text { - Central radiopaque marker enabling the operator to confirm locking in one view } \\
\text { - Proprietary Depth Guard }{ }^{\mathrm{TM}} \text { system reducing rate of permanent pacemaker } \\
\text { implantation and left ventricular tract interaction }\end{array}$ & - Outer sealing and inner skirt at the inflow \\
\hline
\end{tabular}

Figure 2 Comparison of valves' characteristics and special features.

Five studies including 417 Lotus and 1,270 Sapien 3 patients provided data on procedure duration, which was significantly longer in Lotus patients: $83.2 \pm 30.8 \mathrm{vs}$. $67.9 \pm 25.8 \mathrm{~min}(\mathrm{MD} 14.71,95 \% \mathrm{CI}: 4.66-24.77, \mathrm{P}=0.004)$ (Figure $S 1 D)$.

The need to use more than one prosthesis during initial implantation was very low both in Lotus group $(0.17 \%, 1$ of 582 cases) and Sapien 3 group $(0.56 \%, 8$ of 1,434 cases) with no statistical difference between the groups (RR 1.02, 95\% CI: 0.17-5.96, $\left.\mathrm{P}=0.990 ; \mathrm{I}^{2}=0 \%\right)$.

\section{Clinical outcomes}

Based on data from nine studies including 2,469 patients (679 Lotus and 1,790 Sapien 3) PPI was required more than twice as often after Lotus as compared to Sapien 3 implantation (RR 2.30, 95\% CI: 1.95-2.71, P<0.00001; $\mathrm{I}^{2}=0 \%$ ) with corresponding frequency of $36.4 \% v s .15 .3 \%$ respectively (Figure $3 A$ ).

Six studies were included for CVE analysis. Lotus patients were $75 \%$ more likely to have CVE postoperatively as compared to Sapien 3 (RR 1.76, 95\% CI: 1.03-2.99, $\left.\mathrm{P}=0.04 ; \mathrm{I}^{2}=0 \%\right)$. Corresponding event rates were $4.03 \%$ (26 of 645$)$ and $2.69 \%$ (41 of 1,524) respectively (Figure 3B).

No differences regarding 30-day mortality (RR 1.48, 95\% CI: 0.74-2.96, $\left.\mathrm{P}=0.27 ; \mathrm{I}^{2}=8 \%\right)$, MVC (RR 0.82, 95\% CI, 0.54-1.25, $\mathrm{P}=0.36 ; \mathrm{I}^{2}=0 \%$ ), AKI (RR 1.11, $95 \%$ CI: $\left.0.43-2.86, \mathrm{P}=0.82 ; \mathrm{I}^{2}=6 \%\right)$ and occurrence of serious bleeding (RR 0.94, 95\% CI: 0.66-1.33, $\mathrm{P}=0.72 ; \mathrm{I}^{2}=0 \%$ ) were observed between the two devices. Data from seven studies with a total of 2,169 patients were extracted for analysis of 30-day mortality, MVC, and serious bleeding occurrence. Analysis of AKI included 1,710 individuals from four studies (Figure $S 2 A, B, C, D)$. Repeat procedures for valve related dysfunction in 30 days were performed only in three Sapien 3 patients $(0.82 \%)$.

\section{Functional outcomes}

Eight studies including 2,331 patients provided data for PVL analysis. Mild PVL occurred less frequently in Lotus $18.78 \%$ (136 of 724 ) compared to Sapien 3 group 


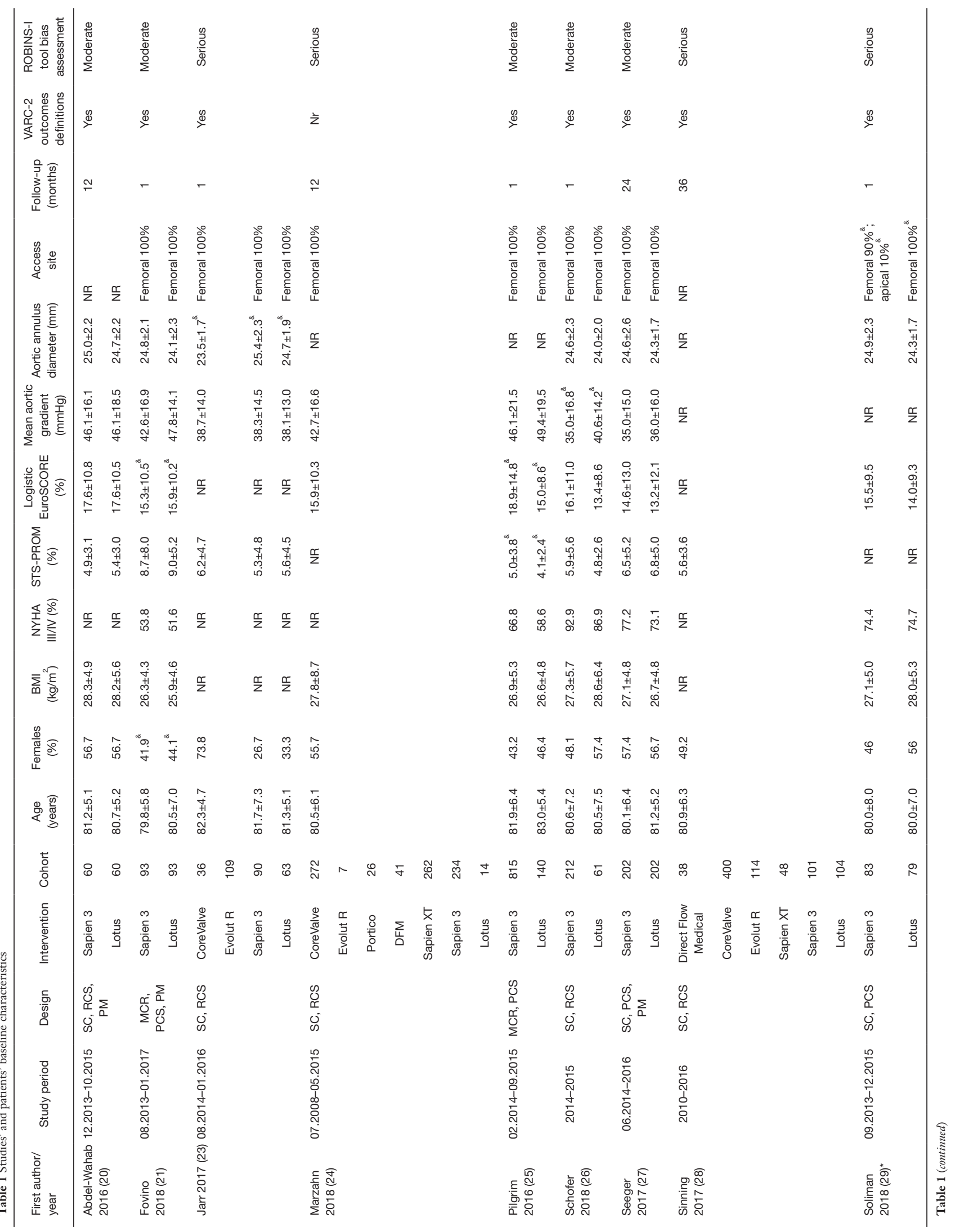




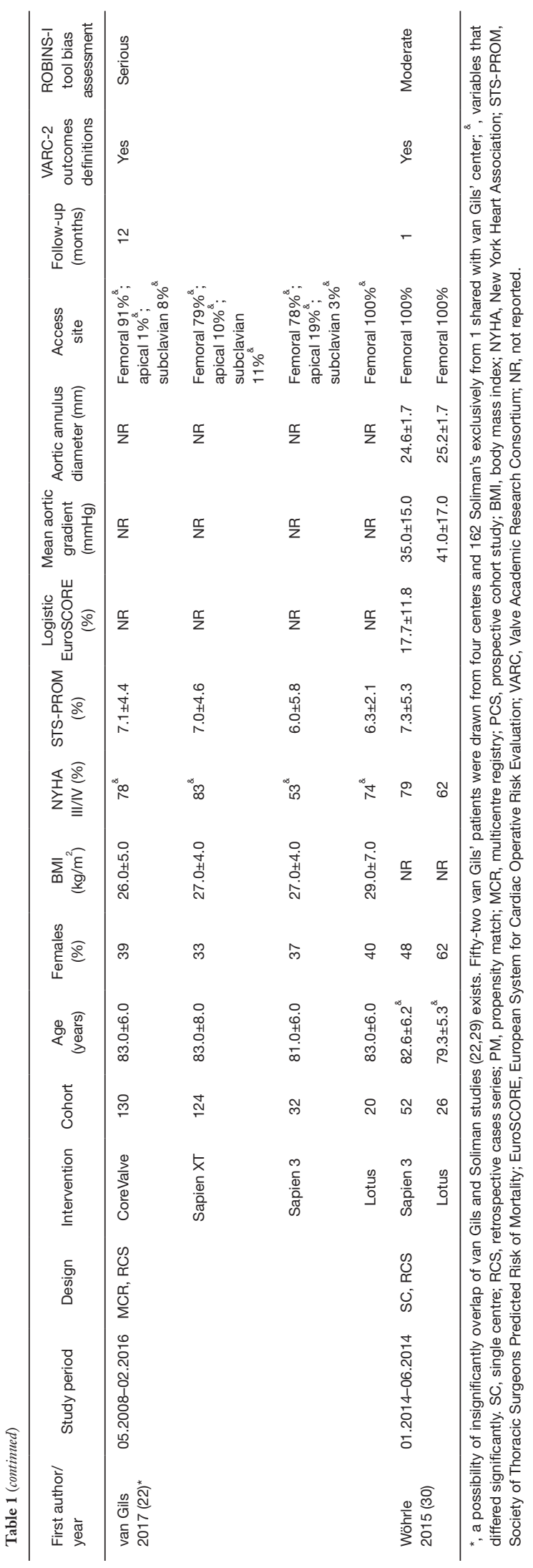

$34.23 \%$ (550 of 1,607); (RR 0.65, 95\% CI: 0.49-0.85, $\mathrm{P}=0.002 ; \mathrm{I}^{2}=45 \%$ ) (Figure $4 A$ ). Moderate to severe PVL was uncommon in both groups however slightly lower in Lotus as compared to Sapien 3 with corresponding rates of $0.36 \%$ (3 of 828 ) and $1.17 \%$ (20 of 1,708) respectively (RR 0.56 , 95\% CI: 0.18-1.77, $\mathrm{P}=0.320 ; \mathrm{I}^{2}=0 \%$ ) (Figure 4B).

Data regarding postprocedural transaortic gradient came from four studies with 1,040 patients. Mean postprocedural transaortic gradients were higher in Lotus patients (MD $0.88 \mathrm{mmHg}$, 95\% CI: $0.24-1.53 \mathrm{mmHg}, \mathrm{P}=0.007$ ) but there was no difference in rate of PPM between Lotus and Sapien 3 recipients (RR 1.10, 95\% CI: $0.82-1.47, \mathrm{P}=0.540 ; \mathrm{I}^{2}=0 \%$ ). Six studies with 459 Lotus and 1,315 Sapien 3 patients provided data for PPM analysis, which occurred in $11.98 \%$ (55 of 459) of patients in Lotus group and 13.76\% (181 of 1,315 ) of patients in Sapien 3 (Figure $5 A, B$ ).

\section{Composite endpoints}

Device success (RR 1.00, 95\% CI: 0.98-1.02, P=0.76; $\left.\mathrm{I}^{2}=0 \%\right)$ and early safety (RR $1.10,95 \%$ CI: $0.79-1.52$, $\mathrm{P}=0.58 ; \mathrm{I}^{2}=0 \%$ ) were similar for both devices. Overall device success and early safety rate was $86.6 \%$ (91.0\% Lotus vs. $84.7 \%$ Sapien 3$)$ and $12.3 \%(11.3 \%$ Lotus vs. $12.6 \%$ Sapien 3), respectively (Figure $S 3 A, B$ ).

\section{Discussion}

To the best of our knowledge this is the first systematic review and meta-analysis of observational trials comparing major procedural, short-term clinical and functional outcomes between the Sapien 3 and Lotus, the nextgeneration valves with external sealing cuffs or skirts with or without mechanisms providing reposition ability to correct a faultily implanted valve which were developed to minimize shortcomings of the early-generation devices. Sapien 3, the next iteration of the balloon-expandable Edwards valve (Edwards Lifesciences, Irvine, California, USA), incorporates an external sealing cuff at the bottom of the stent frame. Having no precursor Lotus Valve System (Boston Scientific Corporation, Marlborough, Massachusetts, USA) is the mechanically-expanded, repositionable and retrievable device contains the adaptive seal at the outer side of frame, located in the left ventricular outflow tract.

Our analysis, by pooling data from eleven studies, demonstrated excellent data regarding short-term performance of both devices. Compared populations of 
A

\begin{tabular}{|c|c|c|c|c|c|c|}
\hline \multirow{2}{*}{ Study or Subgroup } & \multicolumn{2}{|c|}{ LOTUS } & \multicolumn{2}{|c|}{ SAPIEN 3} & \multirow{2}{*}{ Weight } & \multirow{2}{*}{$\begin{array}{c}\text { Risk Ratio } \\
\text { IV, Random. 95\% }\end{array}$} \\
\hline & jents & otal & Events & Total & & \\
\hline Abdel-Wahab 2016 & 31 & 60 & 11 & 60 & $7.7 \%$ & $2.82[1.57,5.07]$ \\
\hline Fovino 2018 & 26 & 93 & 9 & 93 & $5.4 \%$ & $2.89[1.43,5.83]$ \\
\hline Jarr 2017 & 23 & 63 & 17 & 90 & $9.2 \%$ & $1.93[1.13,3.31]$ \\
\hline Marzahn 2017 & 3 & 14 & 38 & 234 & $2.4 \%$ & $1.32[0.46,3.75]$ \\
\hline Pilgrin & 48 & 140 & 113 & 815 & $32.4 \%$ & $2.47[1.86,3.29]$ \\
\hline Scho & 21 & 61 & 41 & 212 & $13.6 \%$ & $4,2.77]$ \\
\hline & 73 & 202 & 31 & 202 & $\%$ & , 3.42] \\
\hline van & 15 & 20 & 11 & 32 & $9.0 \%$ & 2.18[ \\
\hline Wohrle 2015 & 7 & 26 & 2 & 52 & $1.2 \%$ & $7.00[1.56,31.35]$ \\
\hline Total $(95 \% \mathrm{Cl})$ & & 679 & & 1790 & $100.0 \%$ & $2.30[1.95,2.7$ \\
\hline Total events & 247 & & 273 & & & \\
\hline Heterogeneit & 00. & & $d f$ & & & \\
\hline
\end{tabular}

B

\begin{tabular}{|c|c|c|c|c|c|c|}
\hline Study or Subgroup & Events & Total & Events & Total & Weight & IV, Random, 95\% CI \\
\hline Abdel-Wahab 2016 & 2 & 60 & 0 & 60 & $3.1 \%$ & $5.00[0.25,102.00]$ \\
\hline Fovino 2018 & 4 & 93 & 1 & 93 & $6.0 \%$ & $4.00[0.46,35.12]$ \\
\hline Jarr 2017 & 3 & 63 & 4 & 90 & $13.2 \%$ & $1.07[0.25,4.62]$ \\
\hline Pilgrim 2016 & 6 & 140 & 25 & 815 & $37.1 \%$ & $1.40[0.58,3.34]$ \\
\hline Scho & 5 & 61 & 7 & 212 & $22.8 \%$ & $.55]$ \\
\hline Seec & 6 & 202 & 3 & 202 & $15.0 \%$ & $1,7.89]$ \\
\hline Wohrle 2015 & 0 & 26 & 1 & 52 & $2.8 \%$ & $0.65[0.03,15.53]$ \\
\hline Total $(95 \% \mathrm{Cl})$ & & 645 & & 1524 & $100.0 \%$ & $1.76[1.03,2.9$ \\
\hline Total events & 26 & & 41 & & & \\
\hline
\end{tabular}

Risk Ratio IV, Random, $95 \% \mathrm{CI}$

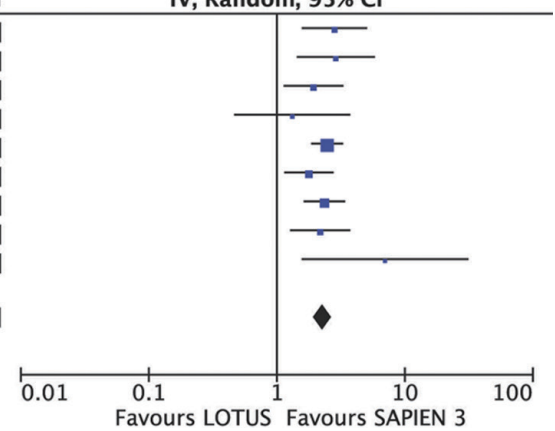

Favours LOTUS Favours SAPIEN 3

Risk Ratio IV, Random, $95 \% \mathrm{CI}$

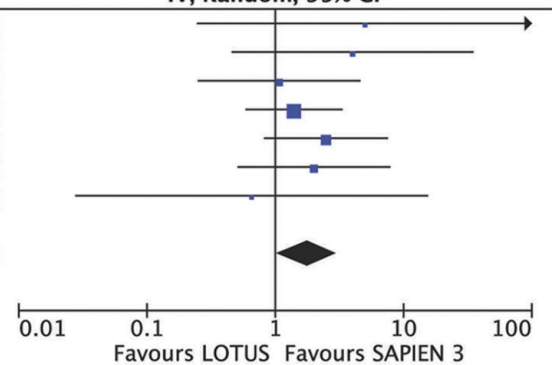

Figure 3 Individual and summary risk ratios with corresponding 95\% confidence intervals for the comparison of Lotus $v s$. Sapien 3 in the analysis of clinical outcomes: permanent pacemaker implantation (A) and cerebrovascular events (B). 95\% CI, 95\% confidence interval.

\begin{tabular}{|c|c|c|c|c|c|c|}
\hline Study or Subgroup & $\begin{array}{r}\text { LOT } \\
\text { Events }\end{array}$ & $\begin{array}{l}\text { JS } \\
\text { Total }\end{array}$ & $\begin{array}{r}\text { SAPIE } \\
\text { Events }\end{array}$ & $\begin{array}{l}\text { N } 3 \\
\text { Total }\end{array}$ & Weight & $\begin{array}{c}\text { Risk Ratio } \\
\text { IV, Random, } 95 \% \mathrm{C}\end{array}$ \\
\hline Abdel-Wahab 2016 & 12 & 60 & 19 & 60 & $11.7 \%$ & $0.63[0.34,1.18]$ \\
\hline Fovino 2018 & 31 & 93 & 25 & 93 & $17.0 \%$ & $1.24[0.80,1$. \\
\hline Jarr 2017 & 10 & 63 & 32 & 90 & $11.5 \%$ & $0.45[0.24,0.8$ \\
\hline Pilgrim 2016 & 39 & 140 & 369 & 815 & $23.5 \%$ & $0.62[0.47,0$. \\
\hline Schofer 2017 & 2 & 61 & 32 & 212 & $3.3 \%$ & $0.22[0.05,0$. \\
\hline Seeger 2017 & 27 & 202 & 40 & 202 & $16.8 \%$ & $0.68[0.43,1$. \\
\hline Soliman 2016 & 12 & 79 & 25 & 83 & $11.9 \%$ & $0.50[0.27,0$. \\
\hline Wohrle 2015 & 3 & 26 & 8 & 52 & $4.1 \%$ & $0.75[0.22,2.5$ \\
\hline Total $(95 \% \mathrm{Cl})$ & & 724 & & 1607 & $100.0 \%$ & $0.65[0.49,0$. \\
\hline Total events & 136 & & 550 & & & \\
\hline
\end{tabular}

Test for overall effect: $Z=3.15(P=0.002)$

B

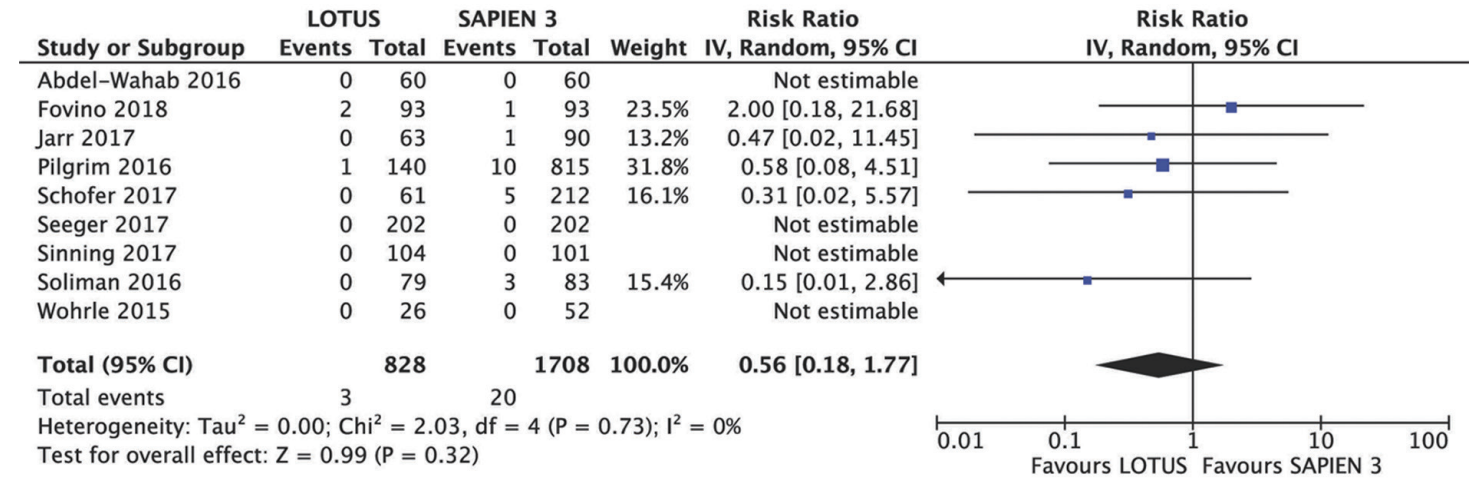

Figure 4 Individual and summary risk ratios with corresponding 95\% confidence intervals for the comparison of Lotus vs. Sapien 3 in the analysis of functional outcomes: mild (A) and moderate/severe (B) paravalvular leak. 95\% CI, 95\% confidence interval. 


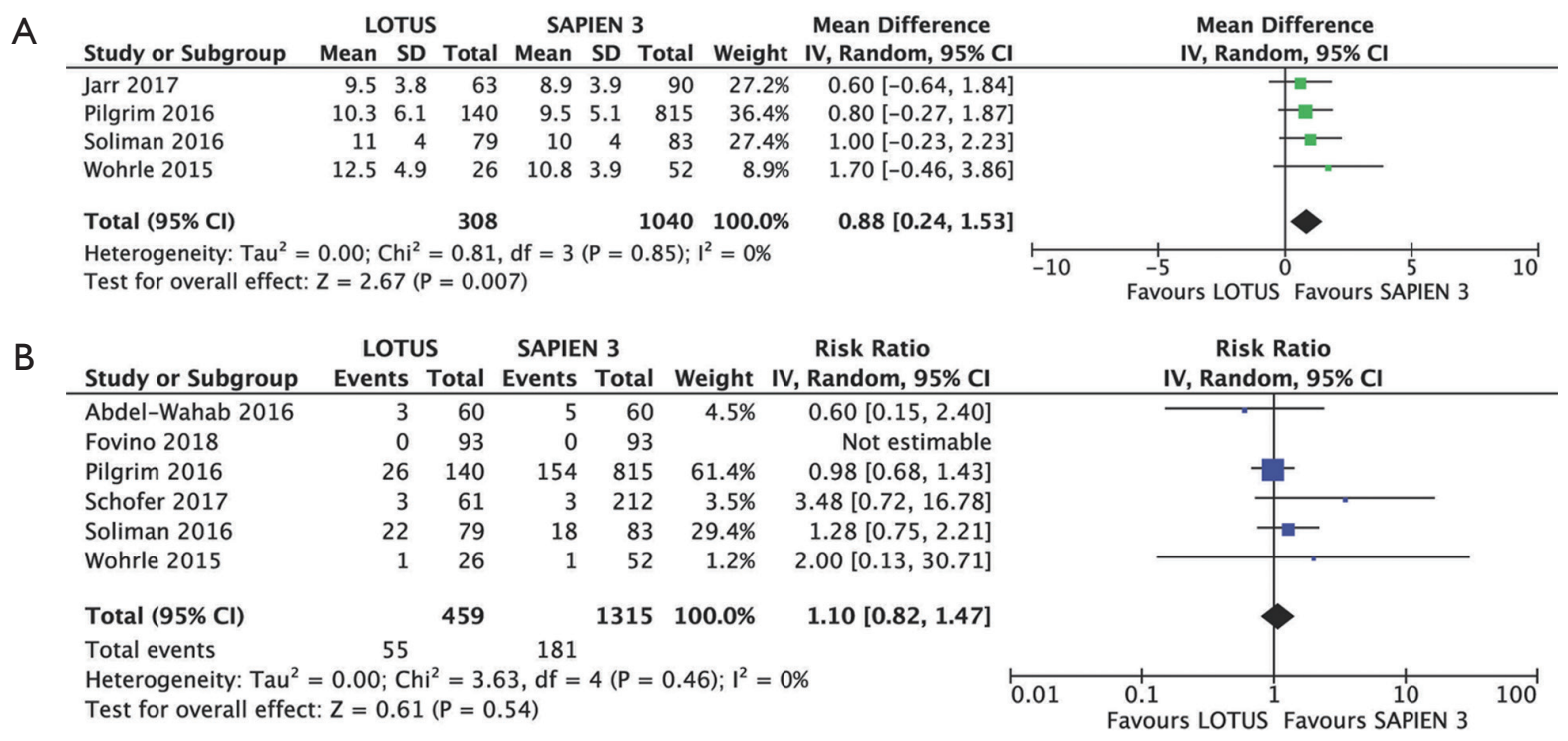

Figure 5 Detailed analysis of individual weighted mean differences (MDs) with corresponding $95 \%$ CIs on postoperative mean aortic gradient for the comparison of Lotus vs. Sapien 3 (A) and individual and summary risk ratios with corresponding $95 \%$ CIs in the analysis of prosthesis-patient mismatch (B). 95\% CI, 95\% confidence interval; SD, standard deviation.

patients seemed to be well balanced with respect to baseline characteristics and severity of underlying valvular disease, although some differences should be highlighted. Patients treated with Lotus were more often female $(\mathrm{P}=0.010$ and received smaller prostheses $(\mathrm{P}<0.001)$.

Major finding of the current study is that the Lotus implantation was associated with increased risk of PPI at cost of mild PVL occurrence. We have also demonstrated higher incidence of CVE in Lotus valve recipients. Other clinical endpoints: 30-day mortality, vascular complications, AKI, as well as life threatening and major bleeding, did not differ between the two groups. The use of Lotus valve has also resulted in a higher postprocedural transprosthetic gradient, but it did not translate into a higher frequency of PPM. Procedures with Lotus were significantly longer and required greater amount of contrast volume. Device success and early safety combined endpoints, defined by VARC-2 criteria, were however similar regardless the type of valve implanted.

Current study revealed significantly lower rate of mild PVL with Lotus compared to Sapien 3 (18.78\% vs. 34.23\% respectively). Moderate to severe aortic regurgitation was seldom in both groups but lower with Lotus $(0.36 \%)$ than with Sapien $3(1.17 \%)$ yet without statistical significance. PVL of different grades was a frequent complication of early-generation TAVR devices and was associated with worse survival (10,31). Moderate to severe PVL occurred in $7.8 \%$ of the self-expandable CoreValve implantation and mild PVL even in one-third of cases (3) in previous studies. The balloon-expandable Sapien XT device was associated with even higher rates of moderate to severe $(9.1 \%)$ and mild (38.0\%) PVL (32). In a randomized study comparing the balloon expandable Edwards Sapien XT with the selfexpandable CoreValve device the risk for moderate or severe PVL was greater in the latter group (12.4\% vs. 42.5\%) (33).

In the next-generations devices, improved by addition an external sealing cuff or a skirt, the frequencies of mild and moderate to severe PVL became significantly lower as compared with the earlier-generation valves. The pooled occurrence of more than mild PVL decreased from $6.9 \%$ Sapien XT to $1.6 \%$ in Sapien 3 valve as in a meta-analysis by Ando et al. with 2,498 patients (34). Similarly, Swiss TAVI Registry including 598 patients, reported decrease of mild $(62.9 \%$ to $41.3 \%)$ and moderate to severe $(5.3 \%$ to $1.3 \%)$ PVL when Sapien 3 device was implanted (35). The PARTNER II SAPIEN-3 trial, that assessed early outcomes after TAVR in inoperable, high-risk and intermediate-risk patients with severe aortic stenosis, showed moderate to severe PVL in $3.4 \%$ and mild in $40.7 \%$ of the cases (36). On the other hand, in Lotus TAVR device recipients, rate of all grade PVL was quite low just from the valve's launch on the market. REPRISE II study reported mild and moderate 
to severe aortic regurgitation in $13.1 \%$ and $2 \%$ of Lotus patients (37), whereas the UK LOTUS registry, in $22.8 \%$ and $0.8 \%$ of patients (38). Our meta-analysis confirms this trend on larger scale with both, mild and moderate to severe PVL rates lower in Lotus as compared to Sapien 3.

Several potential causes of PVL, such as: severe native valve calcification, suboptimal artificial valve sizing, positioning and deployment as well as prosthesis construction itself were universally reported across available literature. Some previous reports noticed that the risk for PVL increases with the extent of landing zone calcification (39-42). Everyday clinical practice shows the Lotus is preferably used in presence of native valve severe calcifications, in particular in case of LVOT involvement. This phenomenon could be explained by higher risk of annular rupture using balloon-expandable valves (43). Schofer et al. demonstrated that the risk for PVL increases with the extent of landing zone calcification also for nextgenerations devices (26). Thus, PVL was significantly less frequent with the Lotus compared to the Sapien 3 valve with increasing extent of calcification. Additionally, the risk of PVL was reduced by $85 \%$ with the Lotus compared to the Sapien 3 valve in these circumstances (26). The fact that Lotus valve implantation has led to significantly lower rate of PVL occurrence, compared to Sapien 3, despite being placed in more demanding environment, could potentially be explained by presence of sealing feature of external cuff. Physical properties of Lotus and Sapien 3 frame seem to be less important since studies showed both valves reaching complete expansion and a circular configuration $(44,45)$.

Long-term follow-up data suggested that even mild PVL was associated with increased late mortality after implantation of the balloon-expandable Edwards Sapien (12) and the CoreValve, early-generation valves $(13,46)$. To date however, no studies exist on late outcomes with Lotus. Therefore, the question if lesser frequency of mild PVL leads to better survival after Lotus implantation remains unanswered.

Another important finding of the present meta-analysis is a significantly higher rate of PPI in Lotus population. In the CHOICE study, that randomized patients to early-generation balloon-expandable Sapien XT and self-expandable CoreValve group, placement of a new permanent pacemaker was necessary in $17.3 \%$ and $37.6 \%$ respectively (33). Fadahunsi et al. evaluated early-generation transcatheter devices and reported PPI in $25.1 \%$ of cases for self-expanding and $4.3 \%$ for balloon-expanding devices (47). In study by Adams et al. the self-expandable CoreValve was also related with higher occurrence of PPI (19.8\%) (3). Smith et al. reported that PPI was required in $3.8 \%$ of cases after the procedure performed with the balloon-expandable Sapien (2).

Changes in the design of next generation devices were supposed to reduce the need for PPI. However, Swiss TAVI Registry revealed the number of PPI increased from $11.0 \%$ in Sapien XT to $17.0 \%$ in Sapien 3 (35). Similarly, Ando et al. in their meta-analysis comparing early- and next-generation Edwards' valves, observed higher rate of PPI in Sapien 3 compared with its predecessor (13\% vs. $10.5 \%, \mathrm{P}=0.07$ ) (34). Early studies showed high rates of PPI in recipients of Lotus TAVR device. REPRISE II study reported PPI in 28.6\% of Lotus patients (37) while the UK LOTUS registry in $31.8 \%$ (38). Some factors can drive high frequency of PPI in Lotus recipients, e.g., physical properties of the valve or/and experience, and therefore technical aspects of prosthesis implantation. Learning curve and number of performed procedures seems to play an important role in minimizing the risk of conduction system damage based on the study by Abdel-Wahab et al. who showed trend towards reduced PPI rate in the Lotus group with increased experience (20). Lotus design and thus high radial forces pressing valve's frame to native annulus and LVOT can affect the conduction system and lead to conduction disturbances. Several previous studies (48-50) indicated the correlation between atrioventricular conduction block and depth of implantation, in particular with depth of more than $6 \mathrm{~mm}$ below the native aortic valve annulus, and highlighted the need of high placement of the early-generation self-expanding prosthesis. Similar risk factors were found by Husser et al. (51) in case of Sapien 3. Study by Krackhardt et al. (52) showed that Lotus implantation in a high annulus position was safe and effective-only $10 \%$ of patient required PPI in a 30-day follow-up. These results confirmed that implantation technique might be particularly meaningful for the reduction of complications related with the Lotus treatment.

Unlike PVL, landing zone calcification burden showed no significant impact on PPI rate (26).

Previous reports, concerning early-generation valves, suggested the transient nature of TAVR-induced conduction disorders, since up to $50 \%$ of the patients with permanent pacemaker were no longer pacemaker dependent at the follow-up (53-55). Alasti et al. reported, only 38\% PPI recipients were pacemaker dependent at 1-year followup after Lotus implantation (56). The true impact of PPI on long-term outcomes after TAVR remains inconclusive $(57,58)$, however, PPI after TAVR was reported as an 
independent predictor of 1-year mortality (58) and was also associated with a longer duration of hospitalization and higher rates of rehospitalization at 1 year (53). On the contrary, in the recent analysis including more than 1,500 TAVR procedures the need for PPI did not increase the overall mortality, cardiovascular death or rehospitalization for heart failure within 2 years (59). Moreover, Engborg et al. reported even higher survival in TAVR-patients with permanent pacemaker implanted (60). Furthermore, valvein-valve TAVR performed with first generation balloon- and self-expandable prosthesis was associated with extremely low rate of PPI (61). Because of artificial ring presence, risk of conduction disturbances is extremely low even for high radial forces bioprostheses.

We have observed higher frequency of CVE in Lotus (4.0\%) compared to Sapien 3 (2.70\%). Similar results were reported in previous studies regarding both devices. CVE occurred in $3.2 \%$ of cases in the UK Lotus registry (38) and in $4.9 \%$ in the REPRISE II (37). The PARTNER II SAPIEN-3 trial (36) showed $2.77 \%$, whereas Swiss TAVI Registry revealed 1.2\% CVE in Sapien 3 group (35).

Systematic review by Auffret et al. including 64 studies with 72,318 patients showed following CVE predictors: female sex, chronic kidney disease, center experience, newonset atrial fibrillation (AF) and postdilatation (\%) (62). In studies included in the current meta-analysis Lotus recipients were usually initial groups treated by using that device. We have had no data on new-onset AF post TAVR in assessed articles, but there were more females and patients with chronic kidney disease in Lotus groups.

In the current study Sapien 3 recipients more commonly required postdilatation and rapid pacing, which could potentially lead to a hemodynamic unstable situation during the implantation process. Despite this CVE rate was lower in this cohort. Repositioning maneuvers with retrievable valves could potentially contribute to increased CVE occurrence. Our meta-analysis revealed at least one recapture maneuver, to optimize valve deployment, was performed in $37.53 \%$ of the Lotus patients (167 of 445).

In study by Schofer et al. (26) more than half of the procedures with the Lotus valve were performed with concomitant use of a cerebral protection device and the risk for CVE did not differ between both groups. On the other hand, dual-filter-based cerebral emboli protection systems could significantly decrease periprocedural ischemic events $(63,64)$. The improvement of implantation technique, along with growing experience, and hence diminish frequency of reposition maneuvers and use of a cerebral protection device might be important aspect of treating patients with Lotus device. Despite statistical significance in the analysis of CVE, differences in risk profiles could have attributed to this result and thus this has to be confirmed in an adequately powered study. In addition, present metaanalysis summarized observational studies alone. The absence of any randomized data inevitably adds to the risk of bias. On the other hand, data are taken from a "real world" which reflects current clinical practice in contrast to randomized trials with highly selected populations. Only half of included studies reported follow-up longer than 1 month. Paucity of data regarding long-term clinical and functional outcomes significantly impedes interpretation of Lotus and Sapien 3 clinical suitability.

\section{Conclusions}

Data shows good short-term implantation outcomes of both Lotus and Sapien 3 valves, with no differences in combined endpoints of device success and early safety. Implantation of Lotus was associated with lower risk of mild PVL at cost of higher risk of PPI and CVE. Remaining clinical and functional outcomes were comparable between both valves. Studies of longer follow-ups are sought to evaluate long-term complications and determine their impact on overall survival.

\section{Acknowledgments}

Funding: None.

\section{Footnote}

Conflicts of Interest: MK serves as the unpaid editorial board member of Fournal of Thoracic Disease from Sep 2018 to Aug 2020. The other authors have no conflicts of interest to declare.

Ethical Statement: The authors are accountable for all aspects of the work in ensuring that questions related to the accuracy or integrity of any part of the work are appropriately investigated and resolved.

Open Access Statement: This is an Open Access article distributed in accordance with the Creative Commons Attribution-NonCommercial-NoDerivs 4.0 International License (CC BY-NC-ND 4.0), which permits the noncommercial replication and distribution of the article with the strict proviso that no changes or edits are made and the 
original work is properly cited (including links to both the formal publication through the relevant DOI and the license). See: https://creativecommons.org/licenses/by-nc-nd/4.0/.

\section{References}

1. Cribier A, Eltchaninoff H, Bash A, et al. Percutaneous transcatheter implantation of an aortic valve prosthesis for calcific aortic stenosis: First human case description. Circulation 2002;106:3006-8.

2. Smith CR, Leon MB, Mack MJ, et al. Transcatheter versus surgical aortic-valve replacement in high-risk patients. $\mathrm{N}$ Engl J Med 2011;364:2187-98.

3. Adams DH, Popma JJ, Reardon MJ, et al., Transcatheter aortic-valve replacement with a self-expanding prosthesis. N Engl J Med 2014;370:1790-8.

4. Webb JG, Pasupati S, Humphries K, et al. Percutaneous transarterial aortic valve replacement in selected high-risk patients with aortic stenosis. Circulation 2007;116:755-63.

5. Leon MB, Smith CR, Mack M, et al. Transcatheter aorticvalve implantation for aortic stenosis in patients who cannot undergo surgery. N Engl J Med 2010;363:1597-607.

6. Thourani VH, Kodali S, Makkar RR, et al. Transcatheter aortic valve replacement versus surgical valve replacement in intermediate-risk patients: a propensity score analysis. Lancet 2016;387:2218-25.

7. Leon MB, Smith CR, Mack MJ, et al. Transcatheter or surgical aortic-valve replacement in intermediate-risk patients. N Engl J Med 2016;374:1609-20.

8. Reardon MJ, Van Mieghem NM, Popma JJ, et al. Surgical or transcatheter aortic valve replacement in intermediaterisk patients. N Engl J Med 2017;376:1321-31.

9. Nishimura RA, Otto CM, Bonow RO, et al. 2017 AHA/ ACC focused update of the 2014 AHA/ACC guideline for the management of patients with valvular heart disease: a report of the American College of Cardiology/American Heart Association task force on clinical practice guidelines. J Am Coll Cardiol 2017;70:252-89.

10. Athappan G, Patvardhan E, Tuzcu EM, et al. Incidence, predictors and outcomes of aortic regurgitation after transcatheter aortic valve replacement: meta-analysis and systematic review of literature. J Am Coll Cardiol 2013;61:1585-95.

11. Van Belle E, Juthier F, Susen S, et al. Postprocedural aortic regurgitation in balloon-expandable and self-expandable transcatheter aortic valve replacement procedures: analysis of predictors and impact on long-term mortality: insights from the FRANCE2 Registry. Circulation
2014;129:1415-27.

12. Kodali SK, Williams MR, Smith CR, et al. Two-year outcomes after transcatheter or surgical aortic-valve replacement. N Engl J Med 2012;366:1686-95.

13. Jones BM, Tuzcu EM, Krishnaswamy A, et al. Prognostic significance of mild aortic regurgitation in predicting mortality after transcatheter aortic valve replacement. J Thorac Cardiovasc Surg 2016;152:783-90.

14. Stroup DF, Berlin JA, Morton SC, et al. Meta-analysis of observational studies in epidemiology: a proposal for reporting. Meta-analysis of observational studies in epidemiology (MOOSE) group. JAMA 2000;283:2008-12.

15. Liberati A, Altman DG, Tetzlaff J, et al. The PRISMA statement for reporting systematic reviews and metaanalyses of studies that evaluate health care interventions: explanation and elaboration. PLoS Med 2009;6:e1000100.

16. Sterne JA, Hernan MA, Reeves BC, et al. ROBINS-I: a tool for assessing risk of bias in non-randomised studies of interventions. BMJ 2016;355:i4919.

17. Kappetein AP, Head SJ, Genereux P, et al. Updated standardized endpoint definitions for transcatheter aortic valve implantation: the Valve Academic Research Consortium-2 consensus document. J Am Coll Cardiol 2012;60:1438-54.

18. Higgins JP, Thompson SG, Deeks JJ, Altman DG. Measuring inconsistency in meta-analyses. BMJ 2003;327:557-60.

19. Wan X, Wang W, Liu J, Tong T. Estimating the sample mean and standard deviation from the sample size, median, range and/or interquartile range. BMC Med Res Methodol 2014;14:135.

20. Abdel-Wahab M, El-Mawardy M, Schwartz B, et al. Comparison of ballon-expandable and mechanicallyexpanded transcatheter aortic valves: Matched comparison from a single center experience. Paper presented at EuroPCR; May 17-20, 2016; Paris, France.

21. Fovino LN, Badawy MRA, Fraccaro C, et al. Transfemoral aortic valve implantation with new-generation devices: the repositionable Lotus vs the balloon-expandable Edwards Sapien 3 valve. J Cardiovasc Med (Hagerstown) 2018;19:655-63.

22. van Gils L, Tchetche D, Lhermusier T, et al. Transcatheter heart valve selection and permanent pacemaker implantation in patients with pre-existent right bundle branch block. J Am Heart Assoc 2017. doi: 10.1161/ JAHA.116.005028.

23. Jarr KU, Leuschner F, Meder B, et al. Initial single-center experience with the fully repositionable transfemoral lotus aortic valve system. J Invasive Cardiol 2017;29:30-5. 
24. Marzahn C, Koban C, Seifert M, et al. Conduction recovery and avoidance of permanent pacing after transcatheter aortic valve implantation. J Cardiol 2018;71:101-8.

25. Pilgrim T, Stortecky S, Nietlispach F, et al. Repositionable versus balloon-expandable devices for transcatheter aortic valve implantation in patients with aortic stenosis. $\mathrm{J}$ Am Heart Assoc 2016;5:e004088.

26. Schofer N, Deushl F, Schon G, et al. Comparative analysis of balloon- versus mechanically-expandable transcatheter heart valves considering landing zone calcification. J Cardiol 2018;71:540-6.

27. Seeger J, Gonska B, Rottbauer W, et al. Outcome with the repositionable and retrievable Boston Scientific Lotus valve compared with the balloon-expandable Edwards Sapien 3 valve in patients undergoing transfemoral aortic valve replacement. Circ Cardiovasc Interv 2017;10:e004670.

28. Sinning JM, Stundl A, Mellert F, et al. Comparison of next generation transcatheter heart valves: Angiographic, echocardiographic and hemodynamic evaluation of an extended all-comers study cohort using the dimensionless aortic regurgitation index. J Am Coll Cardiol 2017;69:S585.

29. Soliman OI, El Faquir N, Ren B, et al. Comparison of valve performance of the mechanically expanding Lotus and the balloon-expanded Sapien 3 transcatheter heart valves: an observational study with independent core laboratory analysis. Eur Heart J Cardiovasc Imaging 2018;19:157-67.

30. Wöhrle J, Gonska B, Rodewald C, et al. Transfemoral aortic valve implantation with the repositionable Lotus valve compared with the balloon-expandable Edwards Sapien 3 valve. Int J Cardiol 2015;195:171-5.

31. Tamburino C, Capodanno D, Ramondo A, et al. Incidence and predictors of early and late mortality after transcatheter aortic valve implantation in 663 patients with severe aortic stenosis. Circulation 2011;123:299-308.

32. Kodali S, Pibarot P, Douglas PS, et al., Paravalvular regurgitation after transcatheter aortic valve replacement with the Edwards sapien valve in the PARTNER trial: characterizing patients and impact on outcomes. Eur Heart J 2015;36:449-56.

33. Abdel-Wahab M, Mehilli J, Frerker C, et al. Comparison of balloon-expandable vs self- expandable valves in patients undergoing transcatheter aortic valve replacement: the CHOICE randomized clinical trial. JAMA 2014;311:1503-14.

34. Ando T, Briasoulis A, Holmes AA, et al. Sapien 3 versus Sapien XT prosthetic valves in transcatheter aortic valve implantation: a meta-analysis. Int J Cardiol 2016;220:472-8.
35. Binder RK, Stortecky S, Heg D, et al. Procedural results and clinical outcomes of transcatheter aortic valve implantation in Switzerland: an observational cohort study of Sapien 3 versus Sapien XT transcatheter heart valves. Circ Cardiovasc Interv 2015. doi: 10.1161/ CIRCINTERVENTIONS.115.002653.

36. Kodali S, Thourani VH, White J, et al. Early clinical and echocardiographic outcomes after Sapien 3 transcatheter aortic valve replacement in inoperable, high-risk, and intermediate-risk patients with aortic stenosis. Eur Heart J 2016;37:2252-62.

37. Meredith Am IT, Walters DL, Dumonteil N, et al. Transcatheter aortic valve replacement for severe symptomatic aortic stenosis using a repositionable valve system: 30 -day primary endpoint results from the REPRISE II study. J Am Coll Cardiol 2014;64:1339-48.

38. Rampat R, Khawaja MZ, Byrne J, et al. Transcatheter aortic valve replacement using the repositionable LOTUS valve. JACC Cardiovasc Interv 2016;9:367-72.

39. Seiffert M, Fujita B, Avanesov M, et al. Device landing zone calcification and its impact on residual regurgitation after transcatheter aortic valve implantation with different devices. Eur Heart J Cardiovasc Imaging 2016;17:576-84.

40. Khalique OK, Hahn RT, Gada H, et al. Quantity and location of aortic valve complex calcification predicts severity and location of paravalvular regurgitation and frequency of post-dilation after balloon-expandable transcatheter aortic valve replacement. JACC Cardiovasc Interv 2014;7:885-94.

41. Leber AW, Kasel M, Ischinger T, et al. Aortic valve calcium score as a predictor for outcome after TAVI using the CoreValve revalving system. Int J Cardiol 2013;166:652-7.

42. Buellesfeld L, Stortecky S, Heg D, et al. Extent and distribution of calcification of both the aortic annulus and the left ventricular outflow tract predict aortic regurgitation after transcatheter aortic valve replacement. EuroIntervention 2014;10:732-8.

43. Barbanti M, Yang TH, Rodes Cabau J, et al. Anatomical and procedural features associated with aortic root rupture during balloon-expandable transcatheter aortic valve replacement. Circulation 2013;128:244-53.

44. Rodríguez-Olivares R, Faquir NE, Rahhab Z, et al. Determinants of image quality of rotational angiography for on-line assessment of frame geometry after transcatheter aortic valve implantation. Int J Cardiovasc Imaging 2016;32:1021-9.

45. Rodríguez-Olivares R, Rahhab Z, Faquir NE, et al. Differences in frame geometry between balloon- 
expandable and self-expanding transcatheter heart valves and association with aortic regurgitation. Rev Esp Cardiol 2016;69:392-400.

46. Little SH, Oh JK, Gillam L, et al. Self-Expanding Transcatheter Aortic Valve Replacement Versus Surgical Valve Replacement in Patients at High Risk for Surgery: A Study of Echocardiographic Change and Risk Prediction. Circ Cardiovasc Interv 2016. doi: 10.1161/ CIRCINTERVENTIONS.115.003426.

47. Fadahunsi OO, Olowoyeye A, Ukaigwe A, et al. Incidence, predictors, and outcomes of permanent pacemaker implantation following transcatheter aortic valve replacement: analysis from the U.S. Society of Thoracic Surgeons/American College of Cardiology TVT Registry. JACC Cardiovasc Interv 2016;9:2189-99.

48. Petronio AS, Sinning JM, Van Mieghem N, et al. Optimal implantation depth and adherence to guidelines on permanent pacing to improve the results of transcatheter aortic valve replacement with the Medtronic CoreValve system: the CoreValve prospective, international, post-market ADVANCE-II study. JACC Cardiovasc Interv 2015;8:837-46.

49. Aktug Ö, Dohmen G, Brehmer K, et al. Incidence and predictors of left bundle branch block after transcatheter aortic valve implantation. Int J Cardiol 2012;160:26-30.

50. Binder RK, Webb JG, Toggweiler S, et al. Impact of postimplant Sapien XT geometry and position on conduction disturbances, hemodynamic performance, and paravalvular regurgitation. JACC Cardiovasc Interv 2013;6:462-8.

51. Husser O, Pellegrini C, Kessler T, et al. Predictors of permanent pacemaker implantations and new-onset conduction abnormalities with the Sapien 3 balloonexpandable transcatheter heart valve. JACC Cardiovasc Interv 2016;9:244-54.

52. Krackhardt F, Kherad B, Krisper M, et al. Low permanent pacemaker rates following Lotus device implantation for transcatheter aortic valve replacement due to modified implantation protocol. Cardiol J 2017;24:250-8.

53. Nazif TM, Dizon JM, Hahn RT, et al. Predictors and clinical outcomes of permanent pacemaker implantation after transcatheter aortic valve replacement: the PARTNER (placement of aortic transcatheter valves) trial and registry. JACC Cardiovasc Interv 2015;8:60-9.

54. Roten L, Stortecky S, Scarcia F, et al. Atrioventricular conduction after transcatheter aortic valve implantation and surgical aortic valve replacement. J Cardiovasc Electrophysiol 2012;23:1115-22.

55. van der Boon RM, Van Mieghem NM, Theuns DA, et al. Pacemaker dependency after transcatheter aortic valve implantation with the self-expanding Medtronic CoreValve System. Int J Cardiol 2013;168:1269-73.

56. Alasti M, Rashid H, Rangasamy K, et al. Long-term pacemaker dependency and impact of pacing on mortality following transcatheter aortic valve replacement with the LOTUS valve. Catheter Cardiovasc Interv 2018;92:777-82.

57. Buellesfeld L, Stortecky S, Heg D, et al. Impact of permanent pacemaker implantation on clinical outcome among patients undergoing transcatheter aortic valve implantation. J Am Coll Cardiol 2012;60:493-501.

58. Dizon JM, Nazif TM, Hess PL, et al. Chronic pacing and adverse outcomes after transcatheter aortic valve implantation. Heart 2015;101:1665-71.

59. Urena M, Webb JG, Tamburino C, et al. Permanent pacemaker implantation after transcatheter aortic valve implantation: impact on late clinical outcomes and left ventricular function. Circulation 2014;129:1233-43.

60. Engborg J, Riechel-Sarup C, Gerke O, et al. Effect of permanent pacemaker on mortality after transcatheter aortic valve replacement. Scand Cardiovasc J 2017;51:40-6.

61. Gozdek M, Raffa GM, Suwalski P, et al. Comparative performance of transcatheter aortic valve-in-valve implantation versus conventional surgical redo aortic valve replacement in patients with degenerated aortic valve bioprostheses: systematic review and meta-analysis. Eur J Cardiothorac Surg 2018;53:495-504.

62. Auffret V, Regueiro A, Del Trigo M, et al. Predictors of early cerebrovascular events in patients with aortic stenosis undergoing transcatheter aortic valve replacement. J Am Coll Cardiol 2016;68:673-84.

63. Van Mieghem NM, Schipper ME, Ladich E, et al. Histopathology of embolic debris captured during transcatheter aortic valve replacement. Circulation 2013;127:2194-201.

64. Haussig S, Mangner N, Dwyer MG, et al. Effect of a cerebral protection device on brain lesions following transcatheter aortic valve implantation in patients with severe aortic stenosis: the CLEAN-TAVI Randomized Clinical Trial. JAMA 2016;316:592-601.

Cite this article as: Gozdek M, Ratajczak J, Arndt A, Zieliński K, Pasierski M, Matteucci M, Fina D, Jiritano F, Meani P, Raffa GM, Malvindi PG, Pilato M, Paparella D, Słomka A, Landes U, Kornowski R, Kubica J, Lorusso R, Suwalski P, Kowalewski M; on behalf of Thoracic Research Centre. Transcatheter aortic valve replacement with Lotus and Sapien 3 prosthetic valves: a systematic review and meta-analysis. J Thorac Dis 2020;12(3):893-906. doi: 10.21037/jtd.2019.12.107 
Table S1 MOOSE checklist for meta-analyses of observational studies

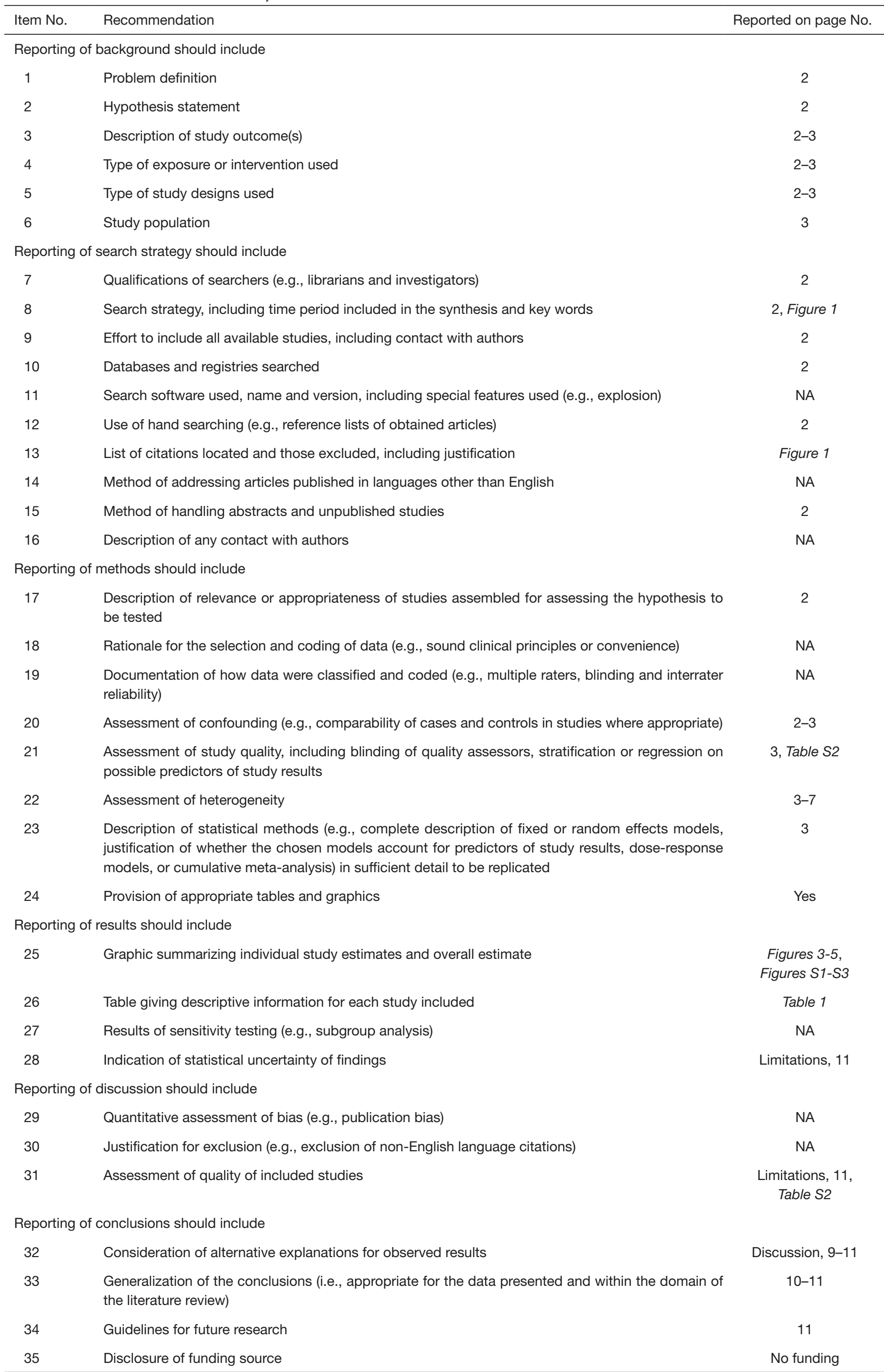

From Stroup DF, Berlin JA, Morton SC, et al. for the Meta-analysis Of Observational Studies in Epidemiology (MOOSE) Group. Metaanalysis of Observational Studies in Epidemiology. A Proposal for Reporting. JAMA 2000;283:2008-12. NA, not reported. 
Table S2 ROBINS-I tool bias assessment

\begin{tabular}{|c|c|c|c|c|c|c|c|c|}
\hline Study & $\begin{array}{l}\text { Bias due to } \\
\text { confounding }\end{array}$ & $\begin{array}{l}\text { Bias in } \\
\text { selection of } \\
\text { participants } \\
\text { into the study }\end{array}$ & $\begin{array}{l}\text { Bias in } \\
\text { measurement } \\
\text { of interventions }\end{array}$ & $\begin{array}{l}\text { Bias due to } \\
\text { departures } \\
\text { from intended } \\
\text { interventions }\end{array}$ & $\begin{array}{l}\text { Bias due to } \\
\text { missing data }\end{array}$ & $\begin{array}{l}\text { Bias in } \\
\text { measurement } \\
\text { of outcomes* }\end{array}$ & $\begin{array}{l}\text { Bias in } \\
\text { selection } \\
\text { of reported } \\
\text { result }\end{array}$ & $\begin{array}{l}\text { Overall } \\
\text { bias }\end{array}$ \\
\hline $\begin{array}{l}\text { Abdel-Wahab } \\
\text { et al. } 2016 \text { (20) }\end{array}$ & Critical & Serious & Low & Low & Low & Serious & Low & Moderate \\
\hline $\begin{array}{l}\text { Jarr et al. } \\
2017 \text { (23) }\end{array}$ & Critical & Critical & Low & Moderate & Low & Serious & Low & Serious \\
\hline $\begin{array}{l}\text { Marzahn et al. } \\
2018(24)\end{array}$ & Critical & Critical & Low & Low & Low & Moderate & Serious & Serious \\
\hline $\begin{array}{l}\text { Seeger et al. } \\
2017 \text { (27) }\end{array}$ & Critical & Serious & Moderate & Low & Low & Serious & Low & Moderate \\
\hline $\begin{array}{l}\text { Sinning et al. } \\
2017 \text { (28) }\end{array}$ & Critical & Critical & Low & Low & Low & Serious & Serious & Serious \\
\hline $\begin{array}{l}\text { Soliman et al. } \\
2018 \text { (29) }\end{array}$ & Critical & Critical & Low & Low & Low & Moderate & Serious & Serious \\
\hline $\begin{array}{l}\text { van Gils L et al. } \\
2017 \text { (22) }\end{array}$ & Critical & Critical & Low & Low & Low & Serious & Serious & Serious \\
\hline
\end{tabular}

*, when multiple outcomes were reported for a study, the highest level of bias at the outcome level is reported in the table. 
Table S3 Studies' inclusion, exclusion criteria. Choice of procedure and valve type

\begin{tabular}{|c|c|c|c|c|}
\hline Study (ref) & Inclusion criteria & Exclusion criteria & $\begin{array}{l}\text { Selection criteria for the } \\
\text { procedure }\end{array}$ & $\begin{array}{l}\text { Selection criteria for the } \\
\text { valve }\end{array}$ \\
\hline $\begin{array}{l}\text { Abdel-Wahab } \\
\text { et al. } 2016(20)\end{array}$ & $\begin{array}{l}\text { Patients treated with new } \\
\text { generation devices }\end{array}$ & $\begin{array}{l}\text { Patients treated with new } \\
\text { generation, self-expanding } \\
\text { devices }\end{array}$ & Not reported & Not reported \\
\hline $\begin{array}{l}\text { Fovino et al. } \\
2017 \text { (21) }\end{array}$ & $\begin{array}{l}\text { All consecutive patients } \\
\text { with symptomatic severe } \\
\text { aortic stenosis undergoing } \\
\text { transfemoral TAVI with Sapien } \\
3 \text { in the PUREVALVE registry } \\
\text { ( } n=93 \text { ) were matched with } \\
\text { patients ( } n=222 \text { ) undergoing } \\
\text { transfemoral TAVI with the } \\
\text { Lotus valve included in the } \\
\text { RELEVANT study }\end{array}$ & $\begin{array}{l}\text { A life expectancy of less than } \\
\text { 1-year, congenital unicuspid } \\
\text { or bicuspid aortic valve, } \\
\text { severe peripheral artery } \\
\text { disease (femoral artery lumen } \\
\text { diameter }<6.0 \mathrm{~mm} \text { ) and valve- } \\
\text { in-valve procedure }\end{array}$ & $\begin{array}{l}\text { Patients were candidate } \\
\text { to TAVI by the local Heart } \\
\text { Team on the basis of } \\
\text { surgical risk score, as well } \\
\text { as frailty and presence of } \\
\text { comorbidities }\end{array}$ & Not reported \\
\hline $\begin{array}{l}\text { Marzahn et al. } \\
2018(24)\end{array}$ & $\begin{array}{l}\text { Patients with high-grade } \\
\text { aortic stenosis who } \\
\text { underwent TAVI }\end{array}$ & Not reported & $\begin{array}{l}\text { All patients were } \\
\text { evaluated for TAVI by an } \\
\text { interdisciplinary heart }\end{array}$ & $\begin{array}{l}\text { Prostheses were selected by } \\
\text { the implanting cardiologist } \\
\text { before intervention based on } \\
\text { the patients' morphology }\end{array}$ \\
\hline $\begin{array}{l}\text { Pilgrim et al. } \\
2016(25)\end{array}$ & $\begin{array}{l}\text { Patients with severe aortic } \\
\text { stenosis treated with the } \\
\text { Edwards Sapien } 3 \text { prosthesis } \\
\text { or the Lotus valve system }\end{array}$ & Not reported & $\begin{array}{l}\text { Selection of TAVI } \\
\text { candidates, device } \\
\text { allocation, and } \\
\text { periprocedural } \\
\text { management was left to the } \\
\text { discretion of the operators }\end{array}$ & $\begin{array}{l}\text { Selection of TAVI } \\
\text { candidates, device } \\
\text { allocation, and } \\
\text { periprocedural management } \\
\text { was left to the discretion of } \\
\text { the operators }\end{array}$ \\
\hline $\begin{array}{l}\text { Seeger et al. } \\
2017(27)\end{array}$ & Not reported & Not reported & $\begin{array}{l}\text { Decision about suitability } \\
\text { for TAVI was assessed by } \\
\text { the heart team }\end{array}$ & $\begin{array}{l}\text { Sapien } 3 \text { was chosen in } \\
\text { annulus diameter }>27 \mathrm{~mm} \\
\text { and short distance annulus } \\
\text { to coronary ostia; Lotus } \\
\text { was chosen in severe left } \\
\text { ventricular outflow tract } \\
\text { calcification and thrombus } \\
\text { in left atrial appendage }\end{array}$ \\
\hline $\begin{array}{l}\text { Sinning et al. } \\
2017(28)\end{array}$ & Not reported & Not reported & Not reported & Not reported \\
\hline $\begin{array}{l}\text { Soliman et al. } \\
2018 \text { (29) }\end{array}$ & $\begin{array}{l}\text { Patients who underwent TAVI } \\
\text { because of severe aortic } \\
\text { stenosis with either the Lotus } \\
\text { or the Sapien } 3\end{array}$ & $\begin{array}{l}\text { Valve-in-valve procedure } \\
\text { or TAVI because of aortic } \\
\text { regurgitation or patients } \\
\text { without echocardiographic } \\
\text { follow-up }\end{array}$ & $\begin{array}{l}\text { Eligibility for TAVI and } \\
\text { vascular access (i.e., } \\
\text { femoral, axillary and apex) } \\
\text { was decided during the } \\
\text { multidisciplinary valve team } \\
\text { discussion }\end{array}$ & $\begin{array}{l}\text { The choice of the valve } \\
\text { type was at the operator's } \\
\text { discretion }\end{array}$ \\
\hline $\begin{array}{l}\text { van Gils et al. } \\
2017 \text { (22) }\end{array}$ & $\begin{array}{l}\text { All consecutive patients } \\
\text { with preexistent right bundle } \\
\text { branch block without a } \\
\text { permanent pacemaker }\end{array}$ & $\begin{array}{l}\text { Transcatheter heart valves } \\
\text { with }<10 \text { cases }\end{array}$ & Not reported & Not reported \\
\hline
\end{tabular}

PUREVALVE, Padua University REVALving Experirnce; RELEVANT, REgistry of Lotus valvE for treatment of aortic VAlve steNosis with Tavr; TAVI, transcatheter aortic valve implantation; SAVR, surgical aortic valve replacement. 
Table S4 Patients' baseline characteristics

\begin{tabular}{|c|c|c|c|c|c|c|c|c|c|c|c|c|c|c|c|c|c|}
\hline Study (ref) & Intervention & $\begin{array}{l}\mathrm{HT} \\
(\%)\end{array}$ & $\begin{array}{l}\mathrm{DM} \\
(\%)\end{array}$ & $\begin{array}{l}\text { PVD } \\
(\%)\end{array}$ & $\begin{array}{l}\text { CKD } \\
(\%)\end{array}$ & $\begin{array}{c}\text { COPD } \\
(\%)\end{array}$ & $\begin{array}{c}\mathrm{PM} / \mathrm{ICD} \\
(\%)\end{array}$ & $\begin{array}{l}\mathrm{AF} \\
(\%)\end{array}$ & $\begin{array}{l}\text { CAD } \\
(\%)\end{array}$ & $\begin{array}{l}\text { MI history } \\
(\%)\end{array}$ & $\begin{array}{c}\text { Stroke } \\
\text { history (\%) }\end{array}$ & $\begin{array}{l}\text { Heart surgery } \\
\text { history (\%) }\end{array}$ & $\begin{array}{l}\text { NYHA } \\
\text { III/IV }\end{array}$ & LVEF (\%) & $\begin{array}{l}\text { Mean aortic } \\
\text { gradient } \\
(\mathrm{mmHg})\end{array}$ & $\begin{array}{l}\text { Aortic valve } \\
\text { area }\left(\mathrm{cm}^{2}\right)\end{array}$ & $\begin{array}{c}\text { Aortic } \\
\text { annulus } \\
\text { diameter }(\mathrm{mm})\end{array}$ \\
\hline \multirow{2}{*}{$\begin{array}{l}\text { Abdel-Wahab } \\
\text { et al. } 2016(20)\end{array}$} & Sapien 3 & NR & NR & NR & NR & NR & NR & $\mathrm{NR}$ & NR & $N R$ & NR & NR & NR & $57.1 \pm 8.8$ & $46.1 \pm 16.1$ & $0.7 \pm 0.2$ & $25.0 \pm 2.2$ \\
\hline & Lotus & NR & NR & NR & NR & NR & NR & NR & NR & NR & NR & NR & NR & $58.9 \pm 9.2$ & $46.1 \pm 18.5$ & $0.7 \pm 0.2$ & $24.7 \pm 2.2$ \\
\hline \multirow{2}{*}{$\begin{array}{l}\text { Fovino et al. } \\
2018 \text { (21) }\end{array}$} & Sapien 3 & 80.6 & 24.7 & NR & NR & 31.2 & 7.5 & 26.9 & 51.6 & NR & 8.6 & 11.8 & 53.8 & NR & $42.6 \pm 16.9$ & $0.80 \pm 0.21$ & $24.8 \pm 2.1$ \\
\hline & Lotus & 82.8 & 28.0 & NR & NR & 29.0 & 11.8 & 22.6 & 46.2 & NR & 12.9 & 16.1 & 51.6 & NR & $47.8 \pm 14.1$ & $0.71 \pm 0.22$ & $24.1 \pm 23.3$ \\
\hline \multirow{2}{*}{$\begin{array}{l}\text { Jarr et al. } \\
2017 \text { (23) }\end{array}$} & Sapien 3 & NR & NR & NR & 4.4 & NR & 13.3 & $\mathrm{NR}$ & $\mathrm{NR}$ & NR & 20 & 11.1 & NR & NR & $38.3 \pm 14.5$ & $0.75 \pm 0.17$ & $25.4 \pm 2.3$ \\
\hline & Lotus & NR & NR & NR & 11.1 & NR & 9.5 & NR & NR & NR & 3 & 23.8 & NR & NR & $38.1 \pm 13.0$ & $0.75 \pm 0.35$ & $24.7 \pm 1.9$ \\
\hline \multirow{2}{*}{$\begin{array}{l}\text { Marzahn et al. } \\
2018 \text { (24) }\end{array}$} & Sapien 3 & NR & NR & NR & NR & NR & NR & NR & $\mathrm{NR}$ & NR & NR & NR & NR & NR & NR & NR & NR \\
\hline & Lotus & NR & NR & NR & NR & NR & NR & NR & NR & NR & NR & NR & NR & NR & NR & NR & NR \\
\hline \multirow{2}{*}{$\begin{array}{l}\text { Pilgrimt } \\
\text { et al. } 2016 \text { (25) }\end{array}$} & Sapien 3 & 76.8 & 24.5 & 15.5 & $N R$ & 11.2 & 9.8 & $N R$ & 58.5 & 15.0 & 11.2 & 14.0 & 66.8 & $55.1 \pm 14.4$ & $46.1 \pm 21.5$ & $0.71 \pm 0.23$ & NR \\
\hline & Lotus & 81.4 & 23.6 & 7.9 & NR & 7.9 & 10.7 & NR & 60.7 & 15.0 & 10.0 & 10.0 & 58.6 & $56.1 \pm 12.1$ & $49.4 \pm 19.5$ & $0.66 \pm 0.22$ & NR \\
\hline \multirow{2}{*}{$\begin{array}{l}\text { Schofer N } \\
\text { et al. } 2018 \text { (26) }\end{array}$} & Sapien 3 & NR & 14.6 & 19.8 & 3.8 & 18.9 & 9.9 & $\mathrm{NR}$ & 59.4 & 12.8 & 14.2 & 6.6 & 92.9 & NR & $35.0 \pm 16.8$ & $0.8 \pm 0.2$ & $24.6 \pm 2.3$ \\
\hline & Lotus & NR & 16.4 & 19.7 & 8.2 & 13.1 & 11.5 & NR & 61.7 & 14.7 & 21.3 & 3.3 & 86.9 & NR & $40.6 \pm 14.2$ & $0.8 \pm 0.3$ & $24.0 \pm 2.0$ \\
\hline \multirow{2}{*}{$\begin{array}{l}\text { Seeger et al. } \\
2017 \text { (27) }\end{array}$} & Sapien 3 & NR & 25.9 & 81.7 & 29.2 & 37.2 & 6.4 & 36.1 & 61.4 & 11.4 & 14.4 & 10.4 & 77.2 & $57.3 \pm 15.0$ & $35.0 \pm 15.0$ & $0.78 \pm 0.30$ & $24.6 \pm 2.6$ \\
\hline & Lotus & NR & 25.9 & 81.7 & 33.3 & 45.1 & 9.4 & 36.6 & 60.7 & 15.9 & 7.9 & 9.5 & 73.1 & $57.0 \pm 14.8$ & $36.0 \pm 16.0$ & $0.79 \pm 0.33$ & $24.3 \pm 1.7$ \\
\hline \multirow{2}{*}{$\begin{array}{l}\text { Sinning et al. } \\
2017 \text { (28) }\end{array}$} & Sapien 3 & NR & NR & NR & NR & NR & NR & $\mathrm{NR}$ & NR & NR & NR & NR & NR & NR & NR & NR & NR \\
\hline & Lotus & NR & NR & NR & NR & NR & NR & $N R$ & NR & NR & NR & NR & NR & NR & NR & NR & NR \\
\hline \multirow{2}{*}{$\begin{array}{l}\text { Soliman et al. } \\
2018 \text { (29) }\end{array}$} & Sapien 3 & NR & NR & NR & NR & NR & NR & $\mathrm{NR}$ & $\mathrm{NR}$ & NR & NR & NR & 74.4 & NR & NR & NR & $24.9 \pm 2.3$ \\
\hline & Lotus & NR & NR & NR & NR & NR & NR & NR & NR & NR & NR & NR & 74.7 & NR & NR & NR & $24.3 \pm 1.7$ \\
\hline \multirow{2}{*}{$\begin{array}{l}\text { van Gils et al. } \\
2017 \text { (22) }\end{array}$} & Sapien 3 & NR & 41 & 22 & NR & 22 & 0 & 25 & NR & NR & 9 & 37 & 53 & NR & NR & NR & NR \\
\hline & Lotus & NR & 45 & 30 & NR & 30 & 0 & 20 & NR & NR & 20 & 25 & 74 & NR & NR & NR & NR \\
\hline \multirow{2}{*}{$\begin{array}{l}\text { Wöhrle et al. } \\
2015(30)\end{array}$} & Sapien 3 & NR & 31 & 19 & 46 & 67 & 13 & 42 & 40 & 25 & 15 & 13 & 79 & NR & $35.0 \pm 15.0$ & $0.71 \pm 0.17$ & $24.6 \pm 1.7$ \\
\hline & Lotus & NR & 23 & 23 & 31 & 62 & 8 & 38 & 27 & 8 & 4 & 8 & 62 & NR & $41.0 \pm 17.0$ & $0.72 \pm 0.21$ & $25.2 \pm 1.7$ \\
\hline
\end{tabular}

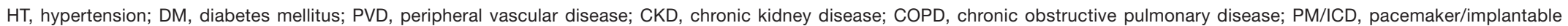
cardioverter-defibrillator; AF, atrial fibrillation; CAD, coronary artery disease; MI, myocardial infarction; LVEF, left ventricle ejection fraction; NR, not reported. 
Table S5 Procedural characteristics

\begin{tabular}{|c|c|c|c|c|c|c|c|c|c|}
\hline Study (ref) & Intervention & Anesthesia & Access site & $\begin{array}{l}\text { Valve sizes } \\
\text { implanted (\%) }\end{array}$ & $\begin{array}{l}\text { Pre-dilatation } \\
(\%)\end{array}$ & $\begin{array}{l}\text { Post-dilatation } \\
\text { (\%) }\end{array}$ & $\begin{array}{l}\text { At least one } \\
\text { reposition } \\
\text { maneuver (\%) }\end{array}$ & $\begin{array}{c}\text { Contrast } \\
\text { volume }(\mathrm{mL})\end{array}$ & $\begin{array}{l}\text { Procedure } \\
\text { duration } \\
\text { (minutes) }\end{array}$ \\
\hline \multirow[t]{2}{*}{$\begin{array}{l}\text { Abdel-Wahab } \\
\text { et al. } 2016 \text { (20) }\end{array}$} & Sapien 3 & NR & NR & $\begin{array}{l}23 \mathrm{~mm} 22.0,26 \mathrm{~mm} \\
51.0,29 \mathrm{~mm} 27.0\end{array}$ & 30 & 8.3 & NA & $N R$ & $57.7 \pm 21.6$ \\
\hline & Lotus & NR & NR & $\begin{array}{l}23 \mathrm{~mm} 23.0,25 \mathrm{~mm} \\
37.0,27 \mathrm{~mm} 40.0\end{array}$ & 33.3 & 0 & NR & NR & $69.3 \pm 19.8$ \\
\hline \multirow[t]{2}{*}{$\begin{array}{l}\text { Fovino et al. } \\
2018(21)\end{array}$} & Sapien 3 & $\begin{array}{l}\text { General or conscious } \\
\text { sedation }\end{array}$ & Femoral $100 \%$ & $\begin{array}{l}23 \mathrm{~mm} 38.7,26 \mathrm{~mm} \\
47.3,29 \mathrm{~mm} 14.0\end{array}$ & 65.3 & 5.3 & NA & $183.0 \pm 72.0$ & $81.0 \pm 22.0$ \\
\hline & Lotus & $\begin{array}{l}\text { General or conscious } \\
\text { sedation }\end{array}$ & Femoral $100 \%$ & $\begin{array}{l}23 \mathrm{~mm} 48.4,25 \mathrm{~mm} \\
31.2,27 \mathrm{~mm} 20.4\end{array}$ & 50.1 & 0 & 26.8 & $241.0 \pm 100.0$ & $107.0 \pm 32.0$ \\
\hline \multirow{2}{*}{$\begin{array}{l}\text { Jarr et al. } \\
2017 \text { (23) }\end{array}$} & Sapien 3 & NR & Femoral $100 \%$ & $N R$ & 57 & 0 & NA & $N R$ & $36.0 \pm 10.0$ \\
\hline & Lotus & NR & Femoral $100 \%$ & $\begin{array}{l}23 \mathrm{~mm} 22.6,25 \mathrm{~mm} \\
27.4,27 \mathrm{~mm} 50.0\end{array}$ & 28 & 0 & 28.6 & $N R$ & $53.0 \pm 17.0$ \\
\hline \multirow{2}{*}{$\begin{array}{l}\text { Marzahn et al. } \\
2018(24)\end{array}$} & Sapien 3 & General $100.0 \%$ & Femoral $100 \%$ & $N R$ & $N R$ & $N R$ & NA & $N R$ & NR \\
\hline & Lotus & General 100.0\% & Femoral $100 \%$ & $N R$ & $N R$ & NR & NR & $N R$ & NR \\
\hline \multirow[t]{2}{*}{$\begin{array}{l}\text { Pilgrim et al. } \\
2016 \text { (25) }\end{array}$} & Sapien 3 & $\begin{array}{l}\text { Conscious sedation } \\
61.5 \% \text {; general } 38.5 \%\end{array}$ & Femoral 100\% & $\begin{array}{l}23 \mathrm{~mm} 26.5,26 \mathrm{~mm} \\
43.1,29 \mathrm{~mm} 30.4\end{array}$ & 81.8 & NR & NA & $152.6 \pm 93.3$ & $70.3 \pm 33.5$ \\
\hline & Lotus & $\begin{array}{l}\text { Conscious sedation } \\
75.0 \% \text {; general } 25.0 \%\end{array}$ & Femoral $100 \%$ & $\begin{array}{l}23 \mathrm{~mm} 31.4,25 \mathrm{~mm} \\
36.4,27 \mathrm{~mm} 32.1\end{array}$ & 31.4 & $N R$ & NR & $177.1 \pm 77.1$ & $69.8 \pm 26.1$ \\
\hline \multirow[t]{2}{*}{$\begin{array}{l}\text { Schofer et al. } \\
2018(26)\end{array}$} & Sapien 3 & $\begin{array}{l}\text { Conscious sedation or } \\
\text { general }\end{array}$ & Femoral $100 \%$ & $N R$ & 55.7 & 17.5 & NA & $150.3 \pm 73.4$ & $94.3 \pm 41.7$ \\
\hline & Lotus & $\begin{array}{l}\text { Conscious sedation or } \\
\text { general }\end{array}$ & Femoral $100 \%$ & $N R$ & 91.8 & 1.6 & 29.5 & $234.4 \pm 102.2$ & $117.1 \pm 58.9$ \\
\hline \multirow[t]{2}{*}{$\begin{array}{l}\text { Seeger et al. } \\
2017 \text { (27) }\end{array}$} & Sapien 3 & $\begin{array}{l}\text { Local anesthesia } \\
\text { under conscious } \\
\text { sedation }\end{array}$ & Femoral $100 \%$ & $\begin{array}{l}23 \mathrm{~mm} \mathrm{37.6,} 26 \mathrm{~mm} \\
38.1,29 \mathrm{~mm} 24.3\end{array}$ & 93.5 & 0 & NA & $80.0 \pm 25.0$ & NR \\
\hline & Lotus & $\begin{array}{l}\text { Local anesthesia } \\
\text { under conscious } \\
\text { sedation }\end{array}$ & Femoral $100 \%$ & 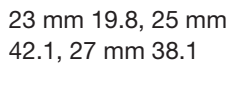 & 87.6 & 0 & 47 & $87.0 \pm 33.0$ & NR \\
\hline \multirow{2}{*}{$\begin{array}{l}\text { Sinning et al. } \\
2017 \text { (28) }\end{array}$} & Sapien 3 & NR & NR & $N R$ & $N R$ & NR & NA & NR & NR \\
\hline & Lotus & NR & NR & NR & NR & NR & NR & NR & NR \\
\hline \multirow[t]{2}{*}{$\begin{array}{l}\text { Soliman et al. } \\
2018 \text { (29) }\end{array}$} & Sapien 3 & General $100.0 \%$ & $\begin{array}{l}\text { Femoral } 90 \% \text {, apical } \\
10 \%,\end{array}$ & $\begin{array}{l}23 \mathrm{~mm} 23.0,26 \mathrm{~mm} \\
47.0,29 \mathrm{~mm} 30.0\end{array}$ & 22 & 13 & NA & $N R$ & NR \\
\hline & Lotus & General $100.0 \%$ & Femoral $100 \%$ & $\begin{array}{l}23 \mathrm{~mm} 33.0,25 \mathrm{~mm} \\
37.0,27 \mathrm{~mm} 30.0\end{array}$ & 15 & 0 & NR & $N R$ & NR \\
\hline \multirow[t]{2}{*}{$\begin{array}{l}\text { van Gils et al. } \\
2017 \text { (22) }\end{array}$} & Sapien 3 & $N R$ & $\begin{array}{l}\text { Femoral } 78 \% \text {, apical } \\
19 \% \text {, subclavian } 3 \%\end{array}$ & $N R$ & NR & NR & NA & NR & NR \\
\hline & Lotus & NR & Femoral $100 \%$ & $N R$ & $N R$ & NR & NR & $N R$ & NR \\
\hline \multirow[t]{2}{*}{$\begin{array}{l}\text { Wöhrle et al. } \\
2015(30)\end{array}$} & Sapien 3 & $\begin{array}{l}\text { Local anesthesia } \\
100 \%\end{array}$ & Femoral $100 \%$ & $\begin{array}{l}23 \mathrm{~mm} 19.0,26 \mathrm{~mm} \\
54.0,29 \mathrm{~mm} 27.0\end{array}$ & $N R$ & 0 & NA & $86.0 \pm 25.0$ & NR \\
\hline & Lotus & $\begin{array}{l}\text { Local anesthesia } \\
100 \%\end{array}$ & Femoral 100\% & $\begin{array}{l}23 \mathrm{~mm} 27.0,25 \mathrm{~mm} \\
04.0,27 \mathrm{~mm} 69.0\end{array}$ & NR & 0 & $38 \%$ & $92.0 \pm 36.0$ & NR \\
\hline
\end{tabular}

NA, not applicable; NR, not reported. 
LOTUS SAPIEN 3 Risk Ratio

Study or Subgroup Events Total Events Total Weight IV, Random, 95\% Cl

\begin{tabular}{lllllll}
\hline Abdel-Wahab 2016 & 20 & 60 & 18 & 60 & $10.7 \%$ & $1.11[0.66,1.88]$
\end{tabular}

Fovino 2018

Jarr 2017

Pilgrim 2016

Schofer 2017

Seeger 2017

Soliman 2016

Wohrle 2015

$\begin{array}{rr}20 & 60 \\ 47 & 93 \\ 28 & 63 \\ 44 & 140 \\ 56 & 61 \\ 177 & 202 \\ 12 & 79 \\ 9 & 26\end{array}$

$59 \quad 93 \quad 13.6 \%$

$0.80[0.62,1.03]$

$\begin{array}{lll}57 \quad 90 & 13.0 \%\end{array}$

$0.70[0.51,0.96]$

$667 \quad 815 \quad 13.7 \%$

$0.38[0.30,0.49]$

$118 \quad 212 \quad 14.4 \%$

$1.65[1.43,1.90]$

$\begin{array}{lll}189 & 202 \quad 14.8 \%\end{array}$

$0.94[0.88,1.00]$

$0.70[0.36,1.36]$

$43 \quad 52 \quad 10.5 \% \quad 0.42[0.24,0.72]$

Total $(95 \% \mathrm{Cl})$

Total events

724

Heterogeneity: $\mathrm{Tau}^{2}=0.19 ; \mathrm{Chi}^{2}=125.48, \mathrm{df}=$

Test for overall effect: $Z=1.55(P=0.12)$

$1607 \quad 100.0 \%$

$0.77[0.56,1.07]$

9

作

B

LOTUS SAPIEN 3

Risk Ratio

Study or Subgroup Events Total Events Total Weight IV, Random, 95\% CI

Abdel-Wahab 2016

060

Fovino 2018

Jarr 2017

Schofer 2017

Seeger 2017

Soliman 2016

Wohrle 2015

Total $(95 \% \mathrm{CI})$

$\begin{array}{lll}\text { Total events } & 1 & 59 \\ \text { Heterogeneity: } \mathrm{Tau}^{2}=0.00 & \mathrm{Chi}^{2}=0.85, \mathrm{df}=4(\mathrm{P}=0.93) ; \mathrm{I}^{2}=0 \%\end{array}$

$0 \quad 93$

063

161

0202

$0 \quad 79$

$\begin{array}{lll}5 & 60 & 16.7 \% \\ 5 & 93 & 16.6 \%\end{array}$

$\begin{array}{ll}5 & 93 \\ 0 & 90\end{array}$

$\begin{array}{rr}0 & 90 \\ 37 & 212\end{array}$

$16.6 \%$

$0.09[0.01,1.61]$

0.09 [0.01, 1.62]

Not estimable

$1202 \quad 13.5 \%$

0.09 [0.01, 0.67]

$0.33[0.01,8.13]$

$0.05[0.00,0.76]$

Not estimable

Test for overall effect: $Z=3.89(P=0.0001)$

$.10[0.03,0.31]$

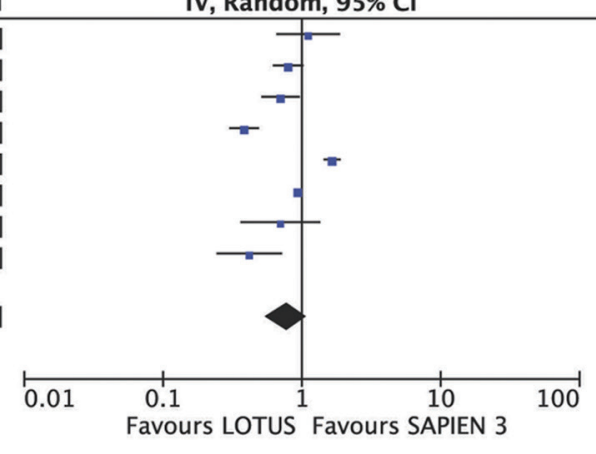

Risk Ratio

IV, Random, 95\% Cl

Risk Ratio

IV, Random, 95\% Cl

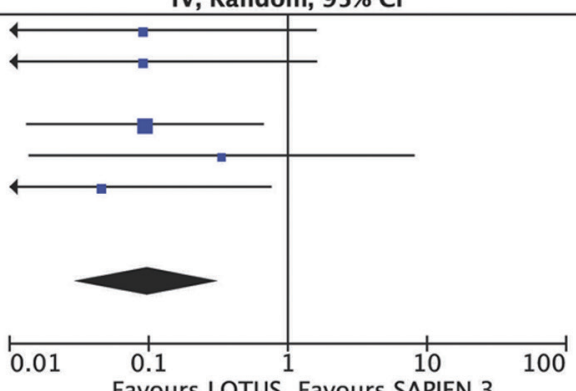

C

\begin{tabular}{|c|c|c|c|c|c|c|c|c|c|c|c|c|}
\hline \multirow[b]{2}{*}{ Study or Subgroup } & \multicolumn{3}{|c|}{ LOTUS } & \multicolumn{3}{|c|}{ SAPIEN 3} & \multirow[b]{2}{*}{ Weight } & \multirow{2}{*}{$\begin{array}{l}\text { Mean Difference } \\
\text { IV, Random, } 95 \% \mathrm{CI}\end{array}$} & \multirow{2}{*}{\multicolumn{3}{|c|}{$\begin{array}{c}\text { Mean Difference } \\
\text { IV, Random, } 95 \% \text { CI }\end{array}$}} & \\
\hline & Mean & SD & Total & Mean & SD & Total & & & & & & \\
\hline Fovino 2018 & 241 & 100 & 93 & 183 & 72 & 93 & $17.9 \%$ & $58.00[32.96,83.04]$ & & & & 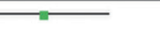 \\
\hline Pilgrim 2016 & 177.1 & 77.1 & 140 & 152.6 & 93.3 & 815 & $21.2 \%$ & $24.50[10.21,38.79]$ & & & & \\
\hline Schofer 2017 & 234.4 & 102.2 & 61 & 150.3 & 73.4 & 212 & $17.1 \%$ & $84.10[56.62,111.58]$ & & & & $\longrightarrow$ \\
\hline Seeger 2017 & 87 & 33 & 202 & 80 & 25 & 202 & $22.9 \%$ & $7.00[1.29,12.71]$ & & & -- & \\
\hline Wohrle 2015 & 92 & 36 & 26 & 86 & 25 & 52 & $20.9 \%$ & $6.00[-9.42,21.42]$ & & & 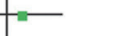 & \\
\hline Total $(95 \% \mathrm{Cl})$ & & & 522 & & & 1374 & $100.0 \%$ & $32.85[10.64,55.07]$ & & & & \\
\hline $\begin{array}{l}\text { Heterogeneity: } \mathrm{Tau}^{2}= \\
\text { Test for overall effect }\end{array}$ & $\begin{array}{l}553.26 \\
Z=2.9\end{array}$ & ; $\mathrm{Chi}^{2}$ & $=45.63$ & $\mathrm{df}=$ & $<0$ & .0000 & $; 1^{2}=91$ & & $\longmapsto_{-100}$ & $\begin{array}{l}-50 \\
\text { Favours LOTUS }\end{array}$ & Favour & $\begin{array}{c}50 \\
\text { APIEN } 3\end{array}$ \\
\hline
\end{tabular}

D

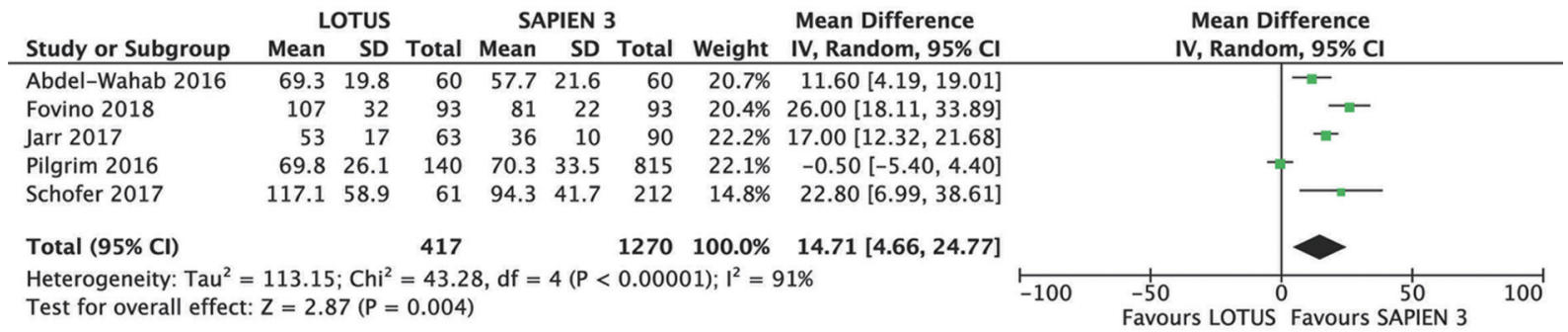

Figure S1 Procedural outcomes. Individual and summary risk ratios with corresponding 95\% confidence intervals (CIs) for the comparison of Lotus vs. Sapien 3 in the analysis of procedural outcomes: predilatation (A) and postdilatation (B). Detailed analysis of individual weighted mean differences (MDs) with corresponding 95\% CIs on contrast volume used (C) and procedure duration (D) for the comparison of Lotus vs. Sapien 3. SD, standard deviation. 
LOTUS SAPIEN 3 Risk Ratio

Study or Subgroup Events Total Events Total Weight IV, Random, 95\% CI \begin{tabular}{lllllll}
\hline Abdel-Wahab 2016 & 1 & 60 & 1 & 60 & $6.2 \%$ & $1.00[0.06,15.62]$
\end{tabular} Fovino 2018 Jarr 2017

Pilgrim 2016

Schofer 2017

Seeger 2017

Wohrle 2015

Total $(95 \% \mathrm{Cl})$

593

63

$\begin{array}{rr}63 \\ 3 & 140\end{array}$

$3 \quad 61$

$\begin{array}{rr}4 & 202 \\ 0 & 26\end{array}$

$\begin{array}{lll}1 & 93 & 10.1 \%\end{array}$

$5.00[0.60,41.98]$

$\begin{array}{llll}1 & 90 & 9.8 \% & 5.71[0.65,49.92]\end{array}$

$\begin{array}{rrrr}1 & 90 & 9.8 \% & 5.715 \\ 23 & 815 & 29.0 \% & 0.76[0.23,2.50]\end{array}$

$\begin{array}{llll}4 & 212 & 20.0 \% & 2.61[0.60,11.33]\end{array}$

$\begin{array}{rrrr}4 & 212 & 20.0 \% & 0.80[0.22,2.94]\end{array}$

Not estimable

Total events

645

$1524 \quad 100.0 \%$

$1.48[0.74,2.96]$

Heterogeneity: $\mathrm{Tau}^{2}=0.07 ; \mathrm{Chi}^{2}=5.46, \mathrm{df}=5(\mathrm{P}=0.36) ; \mathrm{I}^{2}=8 \%$

Test for overall effect: $Z=1.10(P=0.27)$

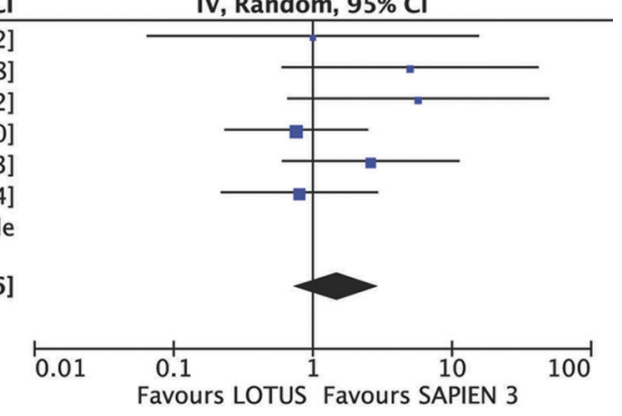

B

LOTUS SAPIEN 3 Risk Ratio

Study or Subgroup Events Total Events Total Weight IV, Random, 95\% Cl Abdel-Wahab 2016

Fovino 2018

Jarr 2017

Pilgrim 2016

Schofer 2017

Seeger 2017

Wohrle 2015

$0 \quad 60$

260

$1.9 \%$

$0.20[0.01,4.08]$

$0.67[0.11,3.90]$

$\begin{array}{lllll}2 & 93 & 3 & 93 & 5.7 \%\end{array}$

163

$3 \quad 90 \quad 3.5 \%$

$0.48[0.05,4.47]$

$0.77[0.41,1.44]$

$\begin{array}{lllll}10 & 140 & 76 & 815 & 44.0 \%\end{array}$

$\begin{array}{lllll}6 & 61 & 20 & 212 & 23.6 \%\end{array}$

$1.04[0.44,2.48]$

$0.86[0.29,2.51]$

$\mathbf{0 . 8 2}[\mathbf{0 . 5 4}, \mathbf{1 . 2 5}]$

Total $(95 \% \mathrm{Cl})$

226

$\begin{array}{rrr}7 & 202 & 15.4 \% \\ 3 & 52 & 5.9 \%\end{array}$

Total events

645

Heterogeneity: $\mathrm{Tau}^{2}=0.00 ; \mathrm{Chi}^{2}=1.77, \mathrm{df}=6(\mathrm{P}=0.94) ; \mathrm{I}^{2}=0 \%$

Test for overall effect: $Z=0.91(P=0.36)$

$1524 \quad 100.0 \%$

$0.82[0.54,1.25]$

IV, Random, 95\% CI

Risk Ratio

IV, Random, $95 \% \mathrm{CI}$

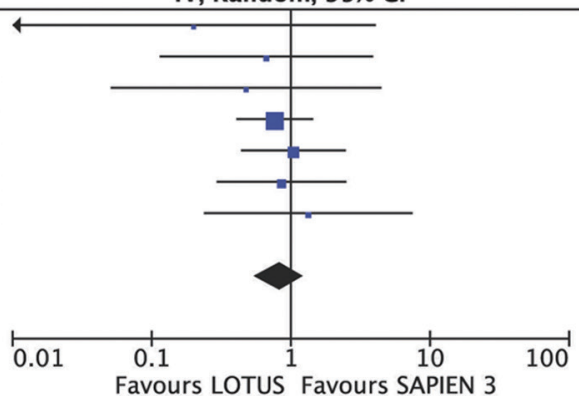

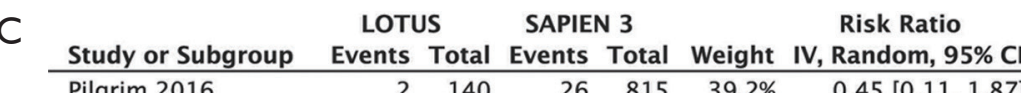

\begin{tabular}{lllllll}
\hline Pilgrim 2016 & 2 & 140 & 26 & 815 & $39.2 \%$ & $0.45[0.11,1.87]$
\end{tabular}

$\begin{array}{lllllll}\text { Schofer } 2017 & 3 & 61 & 4 & 212 & 37.2 \% & 2.61[0.60,11.33]\end{array}$

$\begin{array}{lllllll}\text { Seeger } 2017 & 2 & 202 & 1 & 202 & 14.9 \% & 2.00[0.18,21.88]\end{array}$

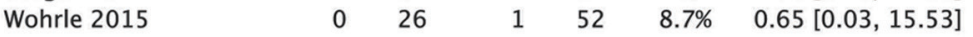

Total $(95 \% \mathrm{Cl})$

429

Total events

7

$1281 \quad 100.0 \% \quad 1.11[0.43,2.86]$

Heterogeneity: $\mathrm{Tau}^{2}=0.06 ; \mathrm{Chi}^{2}=3.19, \mathrm{df}=3(\mathrm{P}=0.36) ; \mathrm{I}^{2}=6 \%$

Test for overall effect: $Z=0.22(P=0.82)$

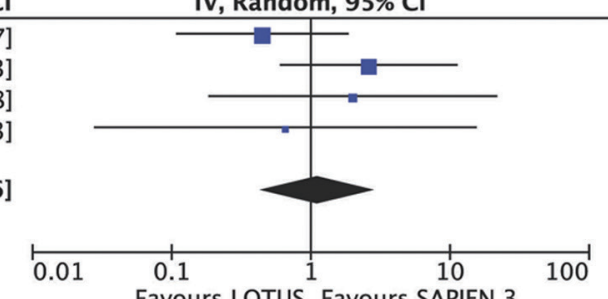

LOTUS SAPIEN $3 \quad$ Risk Ratio

Study or Subgroup Events Total Events Total Weight IV, Random, 95\% C

\begin{tabular}{lllllll}
\hline Abdel-Wahab 2016 & 16 & 60 & 11 & 60 & $26.2 \%$ & $1.45[0.74,2.87]$
\end{tabular}

$\begin{array}{lllllrr}\text { Fovino } 2018 & 4 & 93 & 4 & 93 & 6.6 \% & 1.00[0.26,3.88]\end{array}$

$\begin{array}{lllllll}\text { Jarr } 2017 & 2 & 63 & 5 & 90 & 4.7 \% & 0.57[0.11,2.85]\end{array}$

Pilgrim 2016

Schofer 2017

Seeger 2017

$14 \quad 140$

$\begin{array}{lll}104 & 815 & 43.3 \%\end{array}$

$\begin{array}{lll}20 & 212 \quad 11.3 \%\end{array}$

$0.78[0.46,1.33]$

$0.70[0.25,1.96]$

Wohrle 2015

$4 \quad 202$

$4 \quad 202 \quad 6.4 \%$

$1.00[0.25,3.94]$

$2.00[0.13,30.71]$

Total $(95 \% \mathrm{Cl})$

645

Total events 45

$1524 \quad 100.0 \%$

$0.94[0.66,1.33]$

Heterogeneity: $\mathrm{Tau}^{2}=0.00 ; \mathrm{Chi}^{2}=3.05, \mathrm{df}=6(\mathrm{P}=0.80) ; \mathrm{I}^{2}=0 \%$

Test for overall effect: $Z=0.36(P=0.72)$ 149

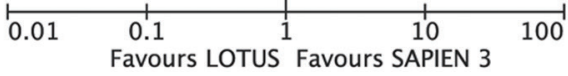

Figure S2 Clinical outcomes. Individual and summary risk ratios with corresponding 95\% confidence intervals (CIs) for the comparison of Lotus $v s$. Sapien 3 in the analysis of clinical outcomes: 30-day all-cause mortality (A); major vascular complications (B); acute kidney injury (C) and serious bleeding (D). 
A

Study or Subgroup Events Total Events Total Weight IV, Random, 95\% Cl

Abdel-Wahab 2016

Fovino 2018

Jarr 2017

Pilgrim 2016

Schofer 2017

Seeger 2017

Total $(95 \% \mathrm{Cl})$

Total events

Heterogeneity: Tau $^{2}=0.00 ; \mathrm{Chi}^{2}=0.91, \mathrm{df}=6(\mathrm{P}=0.99) ; \mathrm{I}^{2}=0 \%$

Test for overall effect: $Z=0.31(P=0.76)$

Risk Ratio
Wohrle 2015

$1.02[0.92,1.13]$

$0.99[0.95,1.03]$

$1.00[0.96,1.03]$

$1.02[0.92,1.12]$

$1.00[0.94,1.06]$

$1.01[0.95,1.07]$

$0.98[0.90,1.07]$

$1.00[0.98,1.02]$

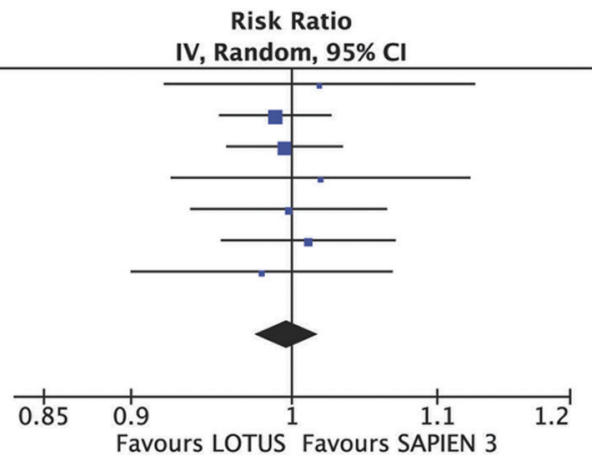

Risk Ratio

B

LOTUS

SAPIEN 3

Random, 95\% Cl

Fovino 2018

Pilgrim 2016

Seeger 2017

Wohrle 2015

Total $(95 \% \mathrm{Cl})$

$\begin{array}{lcc}\text { Total events } & 52 & 147 \\ \text { Heterogeneity: } \mathrm{Tau}^{2}=0.00 ; \mathrm{Chi}^{2}=1.53, \mathrm{df}=3(\mathrm{P}=0.67) ; \mathrm{I}^{2}=0 \%\end{array}$

$\begin{array}{rr}14 & 93 \\ 20 & 140\end{array}$

Events Total

Weight

$1.75[0.77,3.97]$

$0.98[0.63,1.52]$

$\begin{array}{lll}119 & 815 & 55.9 \%\end{array}$

$14 \quad 202 \quad 21.8 \%$

$1.07[0.53,2.16]$

$1.00[0.27,3.68]$

$\begin{array}{rr}15 & 202 \\ 3 & 26\end{array}$

$\begin{array}{lll}6 & 52 & 6.3 \%\end{array}$

Test for overall effect: $Z=0.55(P=0.58)$
$1.10[0.79,1.52]$

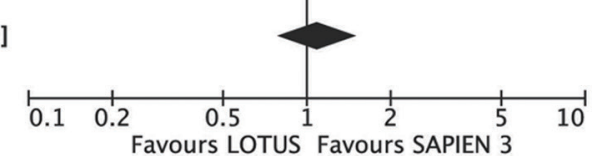

Figure S3 Composite endpoints. Individual and summary risk ratios with corresponding 95\% confidence intervals (CIs) for the comparison of Lotus $v s$. Sapien 3 in the analysis of composite endpoints: device success (A) and early safety (B) according to VARC criteria. 